\title{
Molecular Interpretation of Pharmaceuticals' Adsorption on Carbon Nanomaterials: Theory Meets Experiments
}

\author{
Daniele Veclani *, Marilena Tolazzi and Andrea Melchior
}

Polytechnic Department of Engineering and Architecture, Chemistry Laboratories, University of Udine, via delle Scienze 99, 33100 Udine, Italy; marilena.tolazzi@uniud.it (M.T.); andrea.melchior@uniud.it (A.M.)

* Correspondence: daniele.veclani@uniud.it

Received: 26 April 2020; Accepted: 25 May 2020; Published: 27 May 2020

\begin{abstract}
The ability of carbon-based nanomaterials (CNM) to interact with a variety of pharmaceutical drugs can be exploited in many applications. In particular, they have been studied both as carriers for in vivo drug delivery and as sorbents for the treatment of water polluted by pharmaceuticals. In recent years, the large number of experimental studies was also assisted by computational work as a tool to provide understanding at molecular level of structural and thermodynamic aspects of adsorption processes. Quantum mechanical methods, especially based on density functional theory (DFT) and classical molecular dynamics (MD) simulations were mainly applied to study adsorption/release of various drugs. This review aims to compare results obtained by theory and experiments, focusing on the adsorption of three classes of compounds: (i) simple organic model molecules; (ii) antimicrobials; (iii) cytostatics. Generally, a good agreement between experimental data (e.g. energies of adsorption, spectroscopic properties, adsorption isotherms, type of interactions, emerged from this review) and theoretical results can be reached, provided that a selection of the correct level of theory is performed. Computational studies are shown to be a valuable tool for investigating such systems and ultimately provide useful insights to guide CNMs materials development and design.
\end{abstract}

Keywords: adsorption; carbon nanomaterials; isotherms; drugs; water treatment; molecular dynamics; ab initio calculations; DFT

\section{Introduction}

The first carbon nanomaterial, buckminsterfullerene $\mathrm{C}_{60}$, was discovered in 1985 by Kroto et al. [1]. In 1991, Iijima recognized and fully described carbon nanotubes (CNTs) [2], even though some believe that the discovery was made earlier by Bacon [3]. Novoselov et al. [4] discovered graphene, the thinnest known material in existence [5]. These three materials (shown in Figure 1a-c, respectively) constitute the main classes of carbon nanomaterials (CNMs).

a)

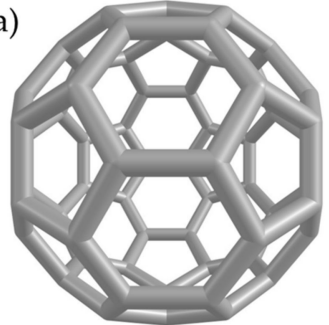

b)

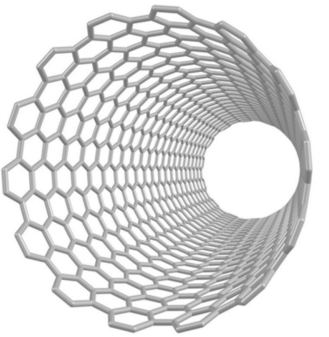

c)

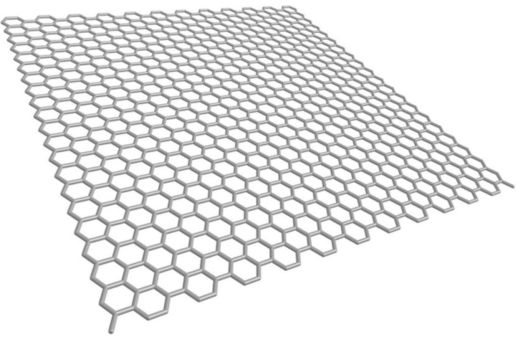

Figure 1. Representation of: (a) Buckminsterfullerene $\mathrm{C}_{60}$; (b) 14-14 armchair single walls carbon nanotubes (SW-CNT); (c) graphene slab. 
The presence of strong carbon-carbon bonding, aromatic structure, reactive sites on the surface obtained through chemical functionalization, and free $\pi$ electrons make them unique materials with exceptional proprieties. Indeed, the high $\pi$ electron density could interact with the molecular orbitals of different compounds, thus facilitating reactions or adsorption [6-8]. Moreover, this peculiar structure provides excellent thermal [9] and electrical conductivity [10-13] and exceptional mechanical properties [14-18].

Fullerenes (Figure 1a) are considered three-dimensional analogues of benzene and are large carbon cage molecules. Buckminsterfullerene $\mathrm{C}_{60}$ with 60 carbon atoms arranged in a spherical structure represent the most abundant form of fullerenes which have a characteristic football shape (a truncated icosahedron) $[19,20]$. In addition to $C_{60}$, there are other different types of fullerenes with numbers of carbon atoms ranging from 38 to 980, and they form different structures with different properties and field of applications [21]. Three main methodologies can be used to produce fullerenes: Huffman-Krätschmer; combustion and microwave methods [22].

The systematic development of covalent fullerene chemistry (i.e., introducing surface modifications) provided an unprecedented diversity of three-dimensional building blocks for technologically interesting materials with different chemical and physical properties, such as increased water solubility and improvement of optical properties, that allow their applications in multiple fields $[23,24]$.

CNTs are allotropes of carbon with a cylindrical three-dimensional (3D) structure formed by rolling single or multiple layers of graphite sheets into seamless cylinders [18,25]. These cylindrical structures could be either single-walled (SW-CNTs) or multi-walled (MW-CNTs) CNTs (Figure 2).
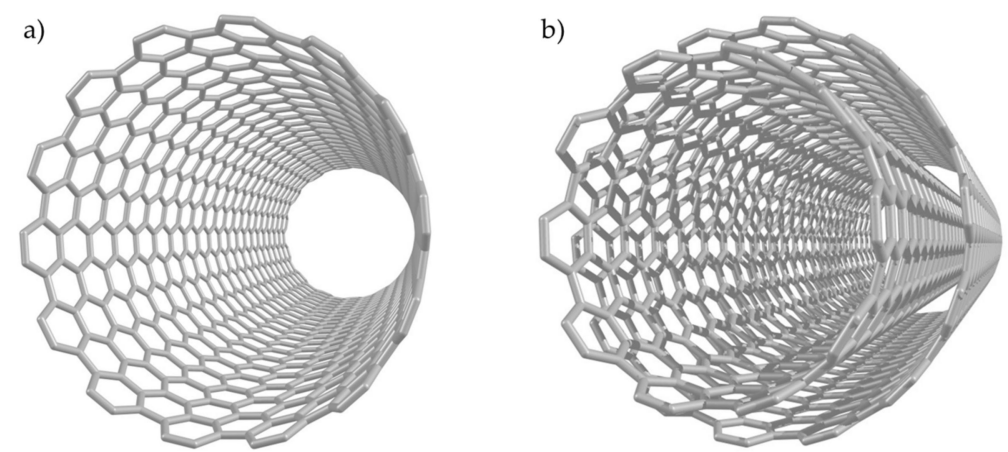

Figure 2. Representation of: (a) 14-14 armchair single walls CNT; (b) multi-walled CNT (MW-CNT): 14-14 armchair CNT and 10-10 armchair CNT.

MW-CNTs generally have a larger outer diameter $(2.5-100 \mathrm{~nm})$ compared to SW-CNTs (0.6-2.4 nm) [9]. CNTs are characterized by unique properties, such as high tensile strength, elasticity, ultra-light weight and excellent chemical and thermal stability [9]. Several techniques have been developed to obtain CNTs; the most common procedures are: arc-discharge [26,27], laser-ablation [28] and catalytic chemical vapor deposition (CVD) [29-31].

CNTs can be functionalized in different ways, to enhance their aqueous solubility and to reduce the tendency to aggregate. Chemical modification can be accomplished in several ways, either covalently or non-covalently [32,33].

Graphene-based materials are two-dimensional (2D) sheets of $\mathrm{sp}^{2}$ carbons arranged in six-membered rings which can be chemically modified to contain a variety of reactive sites [34,35]. The most used forms are single, bi-layer or multi-layer graphene, graphene oxide (GO) and reduced graphene oxide (rGO). Single-layer graphene is synthesized by repeated mechanical exfoliation [4] or controlled growth on substrates like silicon carbide [36] via chemical vapor deposition (CVD) [37]. Graphene oxide (GO) is a highly oxidized form of graphene, chemically modified with carboxylic acid, epoxide and hydroxyl groups in the plane. Carboxylate groups provide colloidal stability and $\mathrm{pH}$ dependent surface charge [38], while epoxide (-O-) and hydroxyl (-OH) groups can interact by 
hydrogen bonding (H-bond) [39]. GO is an amphiphilic molecule, which can be used as a surfactant to stabilize hydrophobic molecules in a solution $[40,41]$. Reduced graphene oxide (rGO) can be obtained by thermal, chemical and ultraviolet (UV) treatment of GO under reducing conditions [38]. rGO is mainly produced to restore the electrical conductivity and optical absorbance in GO while reducing the oxygen content, surface charge, and hydrophilicity [42].

Due to their chemical, mechanical and electrical properties, these classes of CNMs present applications in different fields such as microelectronic devices [43,44], coatings and films [18,45], energy storage [15,46,47], biomedicine [22,24,48-51], and in catalysis [52-54].

As far as medical applications are concerned, $\mathrm{CNM}$ can act as drug carriers, as they can adsorb or encapsulate a variety of organic molecules including pharmaceutical compounds [55-57]. In this way drugs can be delivered on the site of action, protected from degradation, showing increased efficacy [58,59]. Drugs can be loaded into these carriers both by covalent bonds or non-covalent interactions [60-63]. CNM functionalization can be achieved with covalent modification via carboxylation and oxidation [64,65], fluorination [66-68], amidation [69-71], thiolation [72-74], and esterification [75,76]. Molecules can be bound by different bond types such as amide [77-80], disulfide [81-83], ester [78,84,85], and carbamate bonds [86,87]. Non-covalent bonding (van der Waals (vdW), H-bonds, electrostatic interactions) has the advantage to maintain the peculiar properties of these materials $[8,33,63]$ and at the same time a good reversibility of the binding which can be realized by varying environmental conditions, such as $\mathrm{pH}$ [88-97] or temperature [98-101].

Due to the above mentioned chemical and physical features, (high surface/mass ratio, ease of functionalization, cost, mechanical properties), CNMs have been also widely studied for their application as sorbents in water treatment processes, and in particular for the removal of pharmaceuticals from liquid samples [102,103]. The specific treatment of drug-containing wastewaters has become in recent years an important process, as the dispersion of persistent pharmaceutical pollutants in the environment poses serious threats for living organisms [104-107]. The application of adsorption in water treatment presents several advantages (versatility, efficiency, easy implementation in existing plants and low cost $[103,108,109])$ with respect to other techniques, such as advanced oxidation process (AOP) [110,111], bioremediation [112], coagulation [113,114], ozonation [115-117] and reverse osmosis $[118,119]$.

Most of the experimental studies focused on adsorption of a multitude of organic and inorganic drugs such as antibiotics [102,120-122], platinum-based cytostatic drugs (Pt-CD) or other organic antitumor compounds [123-126]. Both kinetic and thermodynamics of adsorption have been investigated deeply. Adsorption equilibrium data were usually fitted with Langmuir [127], Freundlich [128], Temkin [129], Langmuir-Temkin [130], Langmuir-Freundlich [131], Hill [132] isotherms. Several kinetic models have been applied to model the adsorption process, in particular, the pseudo-second-order (PSO) model was shown to better describe the adsorption of drugs by the CNMs [133]. The PSO kinetics was usually associated with the direct adsorption/desorption rate controlling the overall sorption kinetics [134]. However cases that differ from this model are also reported in the literature $[127,132,135,136]$.

The interpretation of kinetic and equilibrium data requires to make hypotheses on the nature of the molecular interactions at play. Different mechanisms have been proposed to control the adsorption of these molecules by CNMs (Figure 3): covalent bonding, hydrophobic interactions, $\pi-\pi$ interactions, electrostatic interactions, H-bonding $[102,120,121,133]$. The relative importance of these contributions is very complex and is still a challenge to be assessed. Spectroscopic studies, such as electronic spectroscopy (UV-Vis) [137], Fourier Transform Infrared Spectroscopy (FT-IR) [138] and Raman [127], X-ray photoelectron spectroscopy (XPS) [127] have been used to provide structural information on adsorption mechanisms. In this respect, theoretical studies have also been demonstrated to be a useful toolbox to disclose the nature and the relative importance of the interactions at play. 


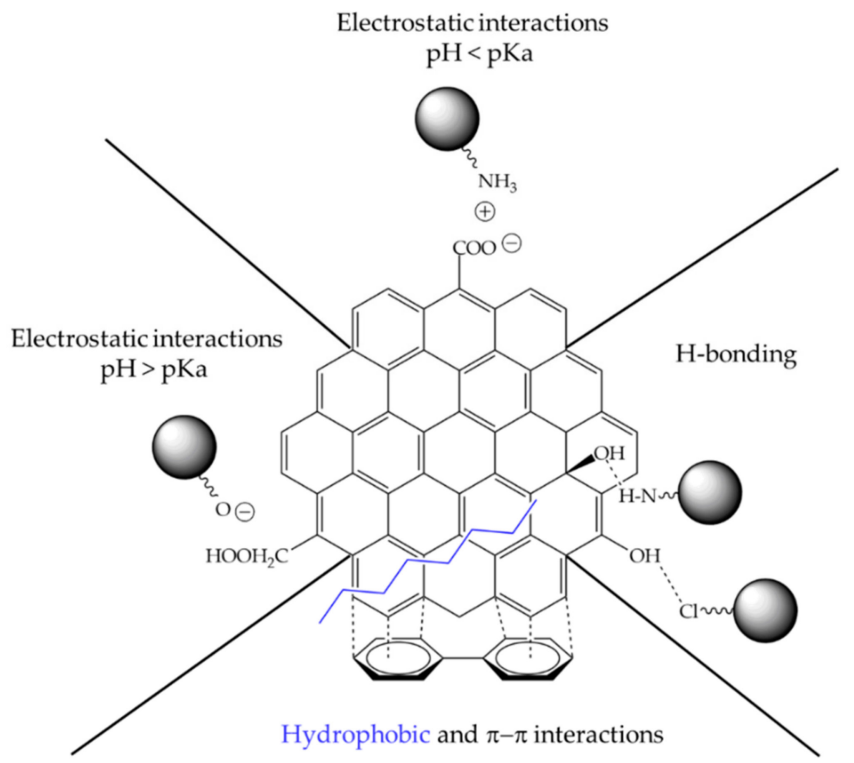

Figure 3. Adsorption mechanisms of drugs on carbon nanomaterials (CNMs).

Quantum mechanical methods, ab-initio and classical molecular dynamics simulations have been the most used techniques employed to study. The nature as well as the size of the studied system guides the type of approach $[139,140]$.

The most used quantum mechanical approach in this field is density functional theory (DFT), which allows one to describe medium to relatively small molecular systems (up to hundreds of atoms) with good accuracy and reasonable computational cost [141,142]. In order to study not only equilibrium structures, but also dynamical behavior, nuclear motion is taken into account in ab-initio molecular dynamics (AIMD) where the forces are obtained by DFT [143]. Typically, such calculations are carried out for replicated supercell structures treated with periodic boundary conditions (PBCs).

In classical molecular dynamics (MD) simulations electronic degrees of freedom are not considered and the motion of the particles is described only through classical mechanics with a physics-based potential energy function, based on the principles of physics. The analytical expression of potential energy (force field) describes intramolecular and intermolecular interactions [144,145]. The most commonly force fields which have been for modelling CNMs are CHARMM [146,147], AMBER [148,149] and GROMOS [150].

Such different computational approaches can provide complementary pieces of information on molecular aspects of adsorption phenomena. For example, quantum chemical methods can be used to calculate adsorption energy ( $E_{a d s}$, i.e., the difference between the energy of the CNM with the molecule adsorbed and the separated components), structural parameters of minimum energy configurations, electronic and spectroscopic properties. On the other hand, MD simulations allow to calculate adsorption free energies $\left(\Delta \mathrm{G}_{\mathrm{ads}}\right)$, structural averages, loading, time-dependent properties (elastic moduli, diffusion coefficients) surface accessible area.

The purpose of this review is to analyze the most recent works concerning theoretical studies of the interactions between several classes of drugs and CNMs and compare them with available experimental data.

The following sections are organized according to the class of compounds interacting with CNMs: (i) Interaction of simple organic compounds with molecular CNMs models; (ii) Adsorption of antimicrobials; (iii) Adsorption/release (delivery) of cytostatic compounds; (iv) Conclusions.

\section{CNMs Models}

A first approach for the theoretical study of the interaction of organic compounds with CNM has been to employ small molecular models which are able to represent portions of their surface. 
In this context, benzene dimer is of key importance as a prototype of aromatic $\pi-\pi$ interactions, and it has been extensively studied both experimentally [151] and theoretically [152-163] a quite common building block of complex organic molecules. Quantum mechanical calculations [157,158,161-163] established that there are two main structures, reported in Figure 4, for the benzene dimer: the first one corresponds to two benzene molecules perpendicular to each other (T-shape) while in the second structure the benzene rings are parallel but their centers are displaced by about $1.6 \AA$ (PD-shape).
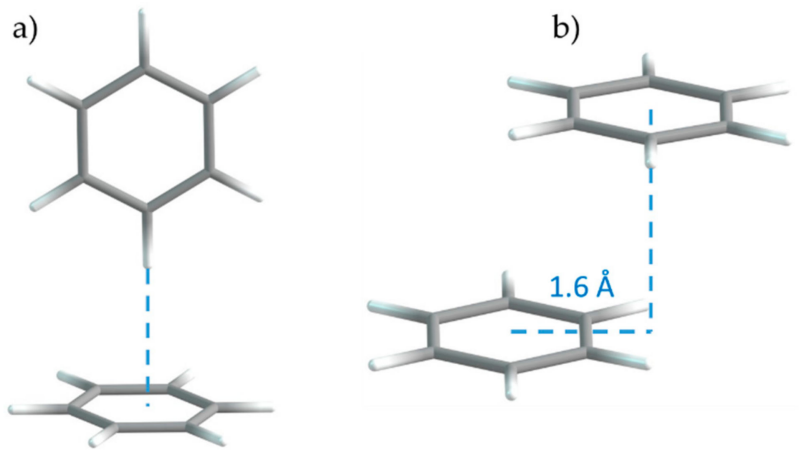

c)

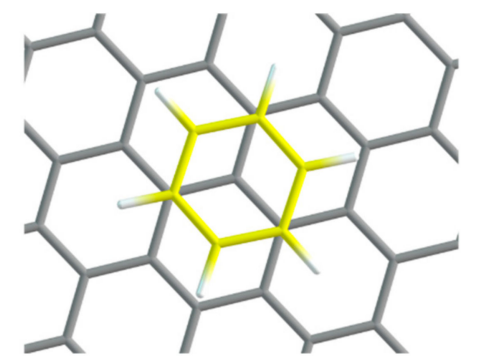

Figure 4. T-shape (a) and PD-shape (b) structures of the benzene dimer and (c) minimum energy structures for graphene-benzene model.

The first model (Figure 4a) is favored by the static quadrupole-quadrupole interaction; dispersion effects favor the second one (Figure $4 b$ ) $[157,164]$. The two structures result almost isoenergetic, and the benzene dimer potential energy surface (PES) is quite flat with several local minima separated by small interconversion barriers [152-163].

Other papers [165-169] concern the study of the interaction between benzene and graphene models such as coronene $\left(\mathrm{C}_{24} \mathrm{H}_{12}\right)$, circumcoronene $\left(\mathrm{C}_{54} \mathrm{H}_{18}\right)$ and larger systems like $\mathrm{C}_{294} \mathrm{H}_{42}$. In contrast to what was observed for the benzene-benzene interaction, when using graphene models, the lowest energy configuration became the face to face orientation, where the global minimum in potential energy surface (PES) is characterized by the structure shown in Figure 4c that differs from PD-shape structure [170]. The $\mathrm{E}_{\mathrm{ads}}$ of a molecule on a graphene surface involves $\pi-\pi$ interactions that explain this kind of arrangement.

The DFT calculation protocol, for systems that are characterized by $\pi-\pi$ type interactions, must use functionals that include dispersion corrections functions. An example is given by the work of Ershova [170] where experimental [171] and theoretical desorption energy $\left(E_{\mathrm{des}}=-\mathrm{E}_{\mathrm{ads}}\right)$ of benzene, napthalene, coronene $\left(\mathrm{C}_{24} \mathrm{H}_{12}\right)$ and ovalene $\left(\mathrm{C}_{32} \mathrm{H}_{14}\right)$ on $\mathrm{C}_{116} \mathrm{H}_{28}$ graphite model have been compared. Two functionals were used; $\omega B 97 X$ [172] which does not include dispersion corrections and the $\omega B 97 X-D$ [173] which provides them. The results (Figure 5) show that $\omega B 97 X$ underestimates the $E_{\text {des }}$ values while the values obtained with $\omega$ B97X-D are in much better agreement with the experimental ones, demonstrating the importance of inclusion of dispersion corrections for a correct estimation of $E_{\text {des }}$. 


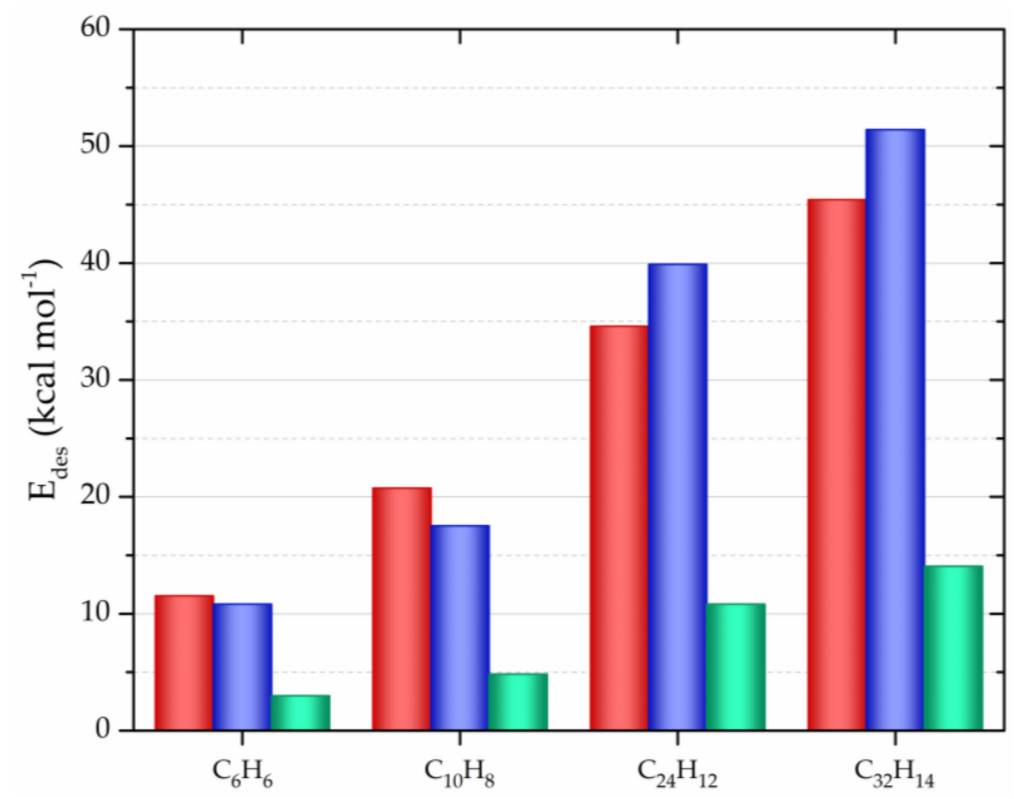

Figure 5. Experimental (red) and theoretical ( $\omega$ B97X-D blue, $\omega B 97 X$ green) $E_{\text {des }}$.

The interaction between CNMs models and substituted benzenes has been also investigated to clarify how the different functional groups can influence the adsorption of these molecules [174-180] and the most interesting works are discussed below.

$E_{\text {des }}$ of 25 small molecules on graphene has been calculated by means of empirical force fields (FF), semiempirical quantum mechanics, and DFT [176]. The $\mathrm{E}_{\mathrm{des}}$ values obtained were compared with the experimental ones obtained by temperature programed desorption (TPD) experiment $[176,181,182]$. The method that best replicated experiments was found to be the dispersion-corrected semiempirical method PM6-DH+. The $\mathrm{E}_{\mathrm{des}}$ of some aromatic molecules (benzene naphthalene and o-dichlorobenzene) were in excellent agreement with the literature data (mean squared errors $<1 \mathrm{kcal} \mathrm{mol}^{-1}$ ) while slightly larger deviations were observed $\left(\sim 2.5 \mathrm{kcal} \mathrm{mol}^{-1}\right)$ for toluene end ethylbenzene as can be seen in Figure 6.

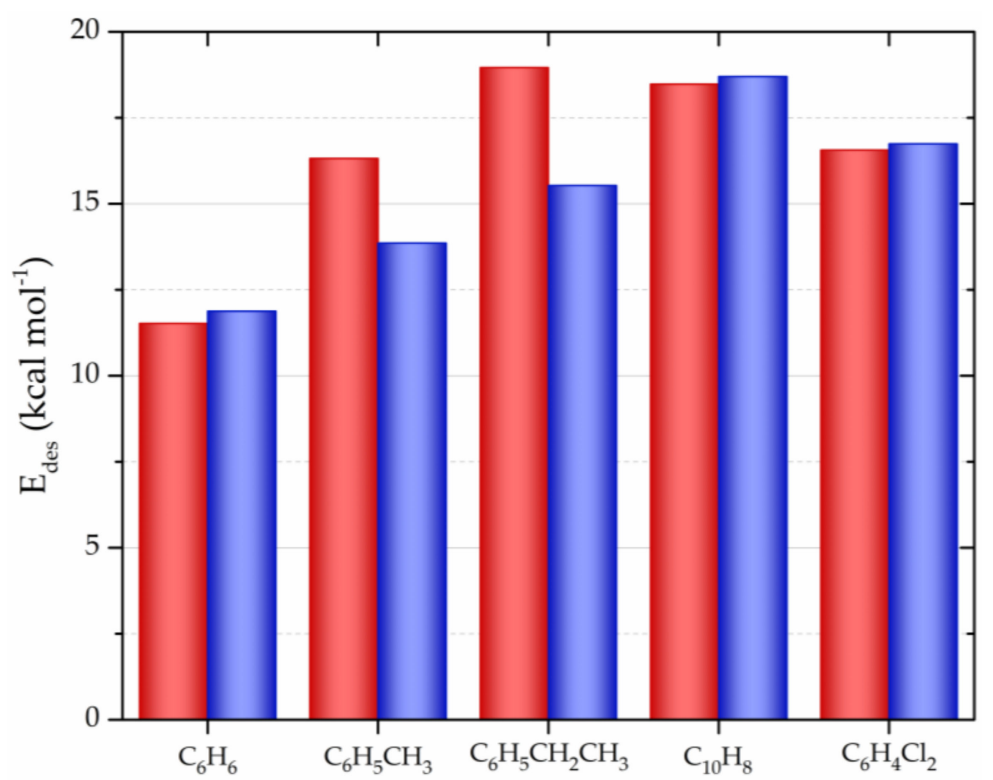

Figure 6. Experimental [181,182] (red) and theoretical [176] (PM6-DH+ blue) $\mathrm{E}_{\mathrm{des}}$. 
In particular, the calculated $E_{\text {des }}$ are systematically lower than the experimental ones. This should be due to the formation of $2 \mathrm{D}$ supramolecular structures: if so, the experimental $\mathrm{E}_{\mathrm{des}}$ could actually correspond to the desorption of dimers or trimers, or to the energy required to destroy the supramolecular structure before desorption.

Similarly, the individual and competitive adsorption of benzene, aniline and naphthylamine on rGO were investigated experimentally and by DFT calculations by Yu et al. [178]. Experimental results indicate that the maximum adsorption capacity follows the order naphthylamine $>$ aniline $>$ benzene both for systems consisting of a single component and for systems consisting of two or three components. DFT calculations well agree with experiments predicting $E_{\text {ads }}$ values that follows the order benzene $<$ aniline $<$ naphthylamine and indicates that the intramolecular interactions between the aromatic compounds themselves have an important influence on their adsorption on the rGOs.

Combined experimental and computational (DFT, MD) techniques were employed also for the study of the adsorption of a set of pyrene derivatives (guest) on the surface of a SW-CNT (host) in order to clarify the mechanisms that originate the host-guest recognition of SW-CNT by small aromatic molecules [180]. The influence of the solvent in the adsorption process was also analyzed: two solvents with markedly different polarity, namely 1,1',2,2' -tetrachloroethane (TCE) and N,N-dimethylformamide (DMF) were used in the experiments. In the nonpolar solvent (TCE), the binding constants resulted to be highly correlated with the contact area between the SW-CNT and the guests. When polar solvent (DMF) is added the binding constants show a complex dependence on the chemical nature of the pyrene substituents: MD simulation confirmed the experimental binding constants measured by means of a thermogravimetric protocol.

Lazar et al. [183] quantified the adsorption enthalpies $\left(\Delta H_{\text {ads }}\right)$ of seven small organic molecules on graphene using theoretical calculations and inverse gas chromatography experiment (Figure 7 , red bars). The best description of dispersion interactions is obtained using the computationally expensive Coupled Cluster (CCSD(T)) method [184]. The $\mathrm{E}_{\text {ads }}$ calculated with this method has been used as reference and were compared with those obtained with different methods. The SCS(MI)-MP2, MP2.5, and MP2.X methods gave reliable results (mean errors of $0.4,0.7$, and $0.7 \mathrm{kcal} \mathrm{mol}^{-1}$ respectively), however MP2 method show a tendency to overestimate the dispersion contribution to the correlation energy has been already observed [185]. The best DFT functional able to reproduce the $\mathrm{E}_{\text {ads }}$ obtained with CCSD(T) method was the hybrid meta-GGA (generalized gradient approximation) M06-2X functional $[186,187]$ with a means error of $0.9 \mathrm{kcal} \mathrm{mol}^{-1}$. Comparison of $E_{\text {ads }}$ calculated by DFT GGA functionals shown that best was the non-local optB88-vdW functional (means error $=1.8 \mathrm{kcal} \mathrm{mol}^{-1}$ ) [188] and it was employed to perform ab initio MD and obtained the $\Delta H_{\text {ads }}$ values (Figure 7, blue bars). B97D functional [189] shown means error of $2.4 \mathrm{kcal} \mathrm{mol}^{-1}$, while the semi-local PBE functional [190-192] shown a slightly negative $\mathrm{E}_{\mathrm{ads}}$.

The experimental $\Delta H_{\text {ads }}$ ranged from $-5.9 \mathrm{kcal} \mathrm{mol}^{-1}$ for dichloromethane to $-13.5 \mathrm{kcal} \mathrm{mol}^{-1}$ for toluene indicating that in all the reported cases the adsorption process is exothermic. Data obtained from ab initio MD showed that all molecules remained bound to the graphene surface during the simulations in contrast to what has been observed with PBE functional, where the molecules spontaneously detached from the graphene surface and this underlines the importance of dispersion [193]. Additionally the average surface molecule distance correspond to physisorption [194], which is a "weak" adsorption process where the single atom holding energy is a few tens of meV's, with no apparent chemical bond formation (chemisorption) [195]. Moreover, the resulting calculated $\Delta \mathrm{H}_{\mathrm{ads}}$ (Figure 7, blue bars) were in excellent agreement with the experimental data [183], indicating that the functional can reproduce chemical phenomena behind adsorption of organic molecules on graphene sufficiently well. 


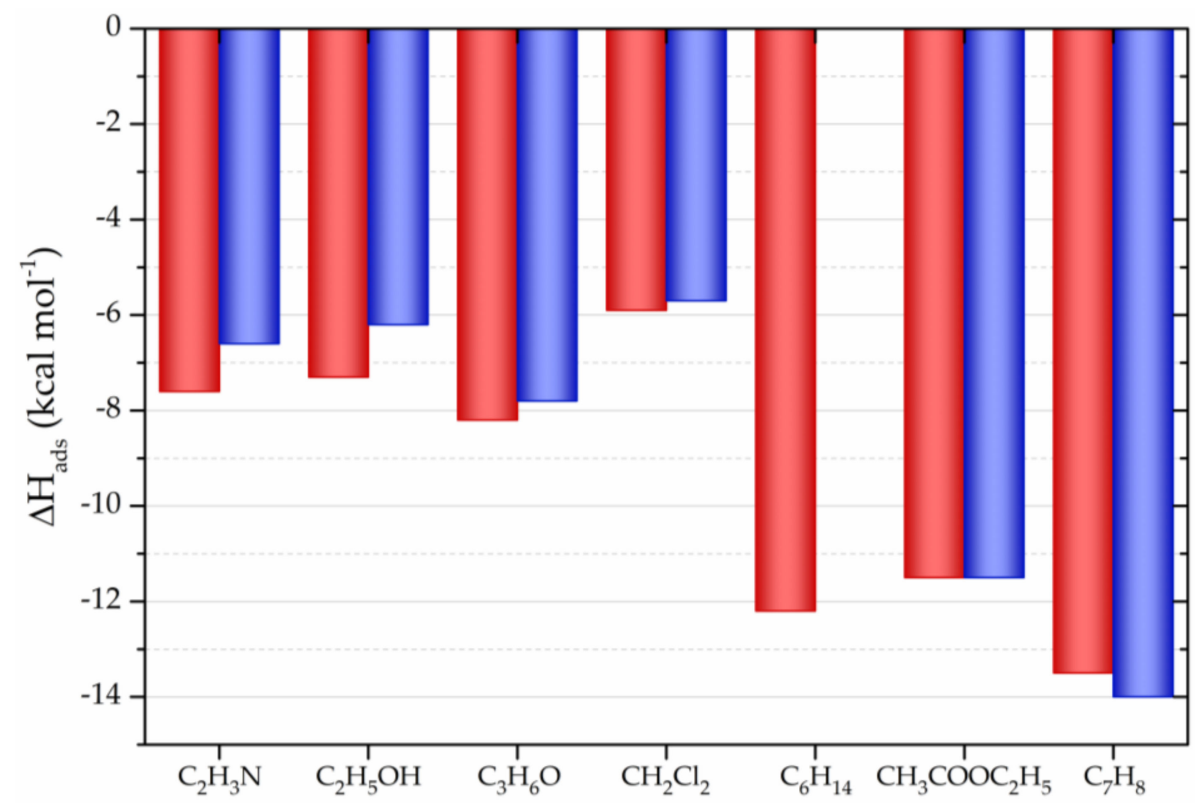

Figure 7. Experimental (red) and theoretical (ab initio molecular dynamics (MD) optB88-vdW, blue) $\Delta \mathrm{H}_{\mathrm{ads}}$, no theoretical data has been reported for hexane $\left(\mathrm{C}_{6} \mathrm{H}_{14}\right)$.

Similarly, the adsorption of about 30 small aromatic compounds on native and hydroxylated SW-CNT was studied and the associated equilibrium constants calculated [177]. The adsorption equilibrium constants $\left(K_{\mathrm{ads}}\right)$ was determined by free-energy calculations and were directly compared to those derived from experiments providing an excellent correlation $(r>0.9)$ [177].

The adsorption capacity of bisphenol A and $17 \alpha$-ethinylestradiol on graphene, SW-CNT and MW-CNT was studied by DFT and MD simulations, with the aim to provide insights for the removal of these endocrine disrupting compounds [174]: a preferential sorption of $17 \alpha$-ethinyl estradiol onto these materials compared to bisphenol A was showed. This observation was consistent with experimental results proving higher removal efficiencies for $17 \alpha$-ethinylestradiol than for bisphenol A. Moreover, MD simulations indicated that the binding free energies, calculated by means of the MM/PBSA approach [196], of bisphenol A and 17 $\alpha$-ethinyl follow the order: graphene $>$ MW-CNTs $>$ SW-CNTs. Experimental results are in line with this trend.

The $\mathrm{pH}$-dependent adsorption of bisphenol A on GO using DFT calculation and MD simulations indicated that the numbers of $\mathrm{H}$-bond between $\mathrm{GO}$ or bisphenol $\mathrm{A}$ and water were higher than the number of H-bond found between bisphenol A and GO [179]. This indicated that the water-mediated $\mathrm{H}$-bond acted as a steering force in the adsorption process. Upon adsorption, the configurations of ionizable organic compounds (IOCs) and GO were changed, and the hydrophilicity was decreased, which may in turn affect their fate and toxicity in the environment.

Nine polybrominated diphenyl ethers (PBDEs) adsorbed on graphene were studied by DFT and MD simulations [175]: the interaction strength between the PBDE molecules and graphene was explained by physisorption and increased with the degree of bromination due to the relatively strong interactions between the bromine atoms. The $E_{a d s}$ exhibited a positive linear correlation with the hydrophobicity of PBDE molecules, while for the PBDEs with 6 or 6 '-substitution, the steric hindrance effect leads to the formation of single $\pi-\pi$ stacking interactions with the graphene surface and thus to a different adsorption behavior.

\section{Antimicrobials}

One of the most significant achievements of the 20th century is the discovery of antimicrobial pharmaceuticals, which have revolutionized both human (Figures 8a, 9 and 10) and veterinary medicine (Figure 8b) [197]. In addition, antibiotics are used at a global scale in livestock and 
aquaculture to increase the production by preventing infections and promoting growth [198]. The global consumption of antibacterial drugs is directly reflected in their presence in various compartments of the environment, including the aquatic one [199]. The excessive use of such antibiotics has led to the emergence of a global environmental pollution problem due to the emergence of drug-resistant bacteria [200-203]. Surface water plays an important role in the emergence and spread of antibiotic resistance, so the development of strategies to improve water quality has become a permanent necessity [197]. In conventional water treatment plants, antimicrobials may predominantly undergo transformation, biodegradation or sorption onto the activated sludge and precipitation, depending on the technology employed [204,205], but, in most cases, they are not completely eliminated and can still be detected in the treated water [206]. Antimicrobial removal through adsorption by using CNM has been widely investigated in the last years, by experimental $[102,127,133,198,207-212]$ and theoretical works [127,132,136,207,211,213-218].

\subsection{Fluoroquinolones}

Fluoroquinolones (FQs) are a group of synthetic antimicrobial agents (Figure 8) with high antibacterial activity against both Gram-negative and Gram-positive bacteria through inhibition of deoxyribonucleic acid DNA gyrase [219].

Numerous research studies on the occurrence and ecotoxicology of FQs in aquatic environments [220] evidenced that FQs are difficult to be biodegraded due to the stable naphthol ring in their structures [221]. In recent years, the alarming increase in the antimicrobial resistance towards FQ has been observed [219,222], thus their removal from water. A selection of adsorption studies on different CNMs, including data related to the loading capacity (LC), adsorption thermodynamic parameters and experimental conditions is reported in Table 1.

a)

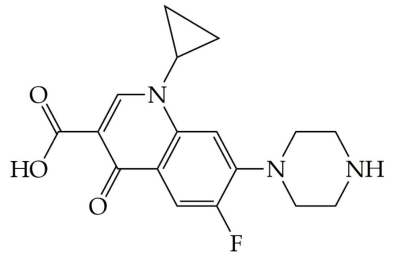

Ciprofloxacin (CFX)<smiles>CC1COC2=C(N3CCN(C)CC3)C(F)=CC3C(=O)C(C(=O)O)CN1C23</smiles>

Ofloxacin (OFL)

b)

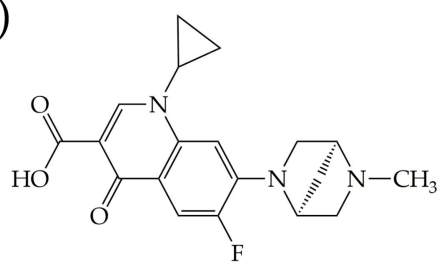

Danofloxacin

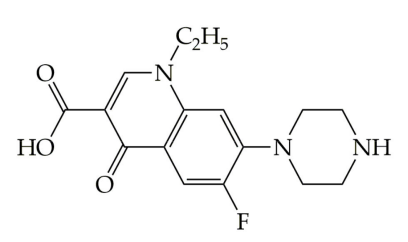

Norfloxacin (NOR)

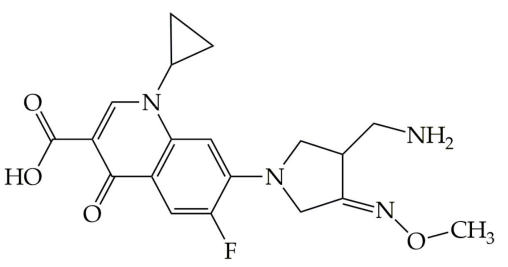

Gemifloxacin

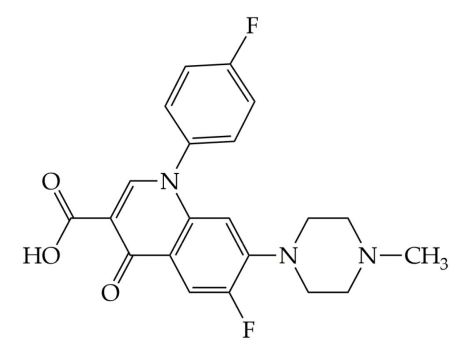

Difloxacin

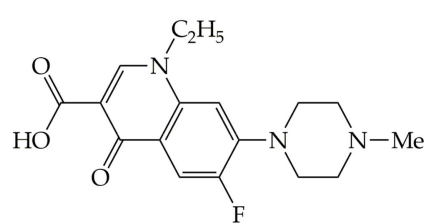

Pefloxacin<smiles>COc1c(N2C[C@H]3CCCN[C@H]3[C@H]2F)c(F)cc2c(=O)c(C(=O)O)cn(C3CC3)c12</smiles>

Moxifloxacin<smiles>CCN1CCN(c2cc3c(cc2F)c(=O)c(C(=O)O)cn3C2CC2)CC1</smiles>

Enrofloxacin

Figure 8. Cont. 


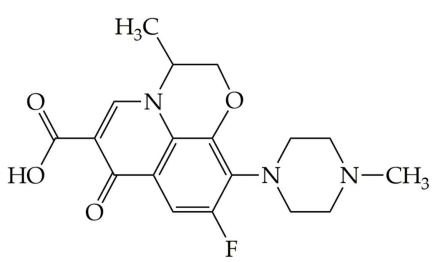

Marbofloxacin

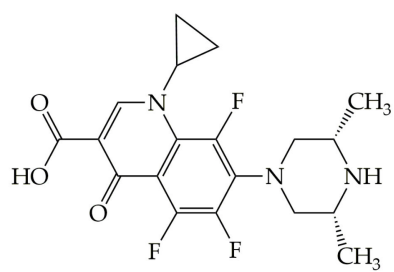

Orbifloxacin

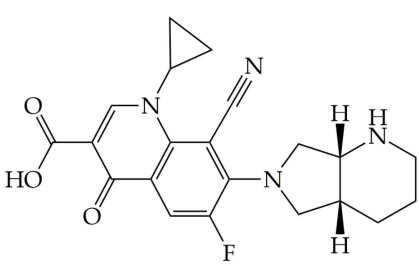

Pradofloxacin

c)
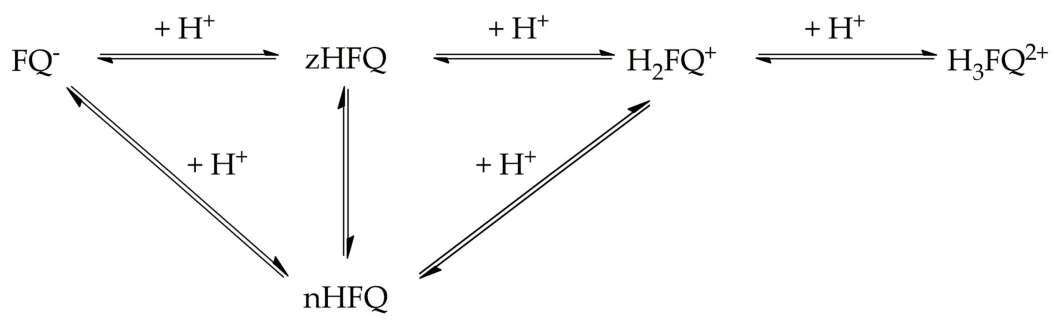

Figure 8. Fluoroquinolones commonly used in human medicine (panel (a)), in veterinary medicine (panel (b)) and protonation equilibria involving micro-species of fluoroquinolones (FQs panel (c)).

The thermodynamic data in Table 1 indicate that, in general, FQs are spontaneously adsorbed by the $C N M s$ with $\Delta \mathrm{G}_{\text {ads }}$ values enclosed in the $-2--10 \mathrm{kcal} \mathrm{mol}^{-1}$ range. These $\Delta \mathrm{G}_{\text {ads }}$, as well as the LC and the type of interactions, depend both on the nature of the CNMs and on the environmental conditions. Especially the $\mathrm{pH}$ has a strong impact on adsorption efficiency of the CNM and this is likely to be linked to the ampholyte nature of FQ. These compounds can exist in five different $\mathrm{pH}$-dependent protonation species, namely: anion $\left(\mathrm{FQ}^{-}\right)$, zwitterions (zHFQ), neutral (nHFQ), cation $\left(\mathrm{H}_{2} \mathrm{FQ}^{+}\right)$and in some cases dication, $\left(\mathrm{H}_{3} \mathrm{FQ}^{2+}\right)$ [223]. A scheme of the equilibria involving such species is reported in Figure 8c.

In particular, it is known that at $\mathrm{pH}=7.0$ the $\mathrm{zHFQ}$ form is largely dominant over the nHFQ one, while at $\mathrm{pH}<6$ and $\mathrm{pH}>9$ the mono-positive and negative species prevail [223], being likely that these species interact differently with the carbon based materials. In agreement with this hypothesis, Li et al. [207] studied experimentally the adsorption of ciprofloxacin (CFX) and found that its adsorption on SW and MW-CNTs was greatly affected by $\mathrm{pH}$. It was proposed that hydrophobic interactions control adsorption for nHCFX and zHCFX, while electrostatic interactions were the dominant mechanism for ionic CFX sorption. In the same study, CFX adsorption resulted thermodynamically favorable for all CNTs used. In the case of SW-CNTs the sorption process is entropy driven (i.e., positive $\Delta H_{\text {ads }}$ ), while it is enthalpy driven on MW-CNTs.

Norfloxacin (NOR) and ofloxacin (OFL) adsorption on MW-CNTs was investigated to evaluate the role of structural and hydrophobic properties in regulating their adsorption [208]. A relationship between adsorption coefficients and specific surface area (highly hydrophobic) was observed, but not between adsorption coefficients and oxygen content of MW-CNT's. This result suggested that site-specific adsorption was not important, but hydrophobic effect may have an important contribution to OFL and NOR adsorption on MW-CNTs.

The normalization of the adsorption coefficients by OFL and NOR solubilities enlarged their adsorption difference indicating that hydrophobicity was not the only factor controlling the difference between OFL and NOR adsorption on MW-CNTs. Both molecules could interact with CNT surface thanks to an electron-donor-acceptor mechanism (EDA). This mechanism was correlated with the different adsorption of OFL and NOR on functionalized MW-CNTs. 
Table 1. Experimental adsorption parameters of FQs on CNMs: Pondus Hydrogenii ( $\mathrm{pH})$, Temperature (K), LC (loading capacity $\left(\mathrm{mg} \mathrm{g}^{-1}\right), \Delta \mathrm{X}\left(\mathrm{kcal} \mathrm{mol}^{-1}\right)$. NA (nalidixic acid), LEV Levofloxacin. G (graphene), G-NS (graphene nano-sheet), GO-MP (graphene oxide magnetic nanoparticle), rGO-MP (reduced graphene oxide magnetic nanoparticle), GO-SA (graphene oxide sodium alginate), GO-CA (graphene oxide calcium alginate), G-H (graphene hydrogel), G-KOH (activated graphene with $\mathrm{KOH}$ ), SW-CNT out (adsorption on outer surface), SW-CNT in (adsorption on inner surface). EMT (external mass transfer), IPD (intra particle diffusion).

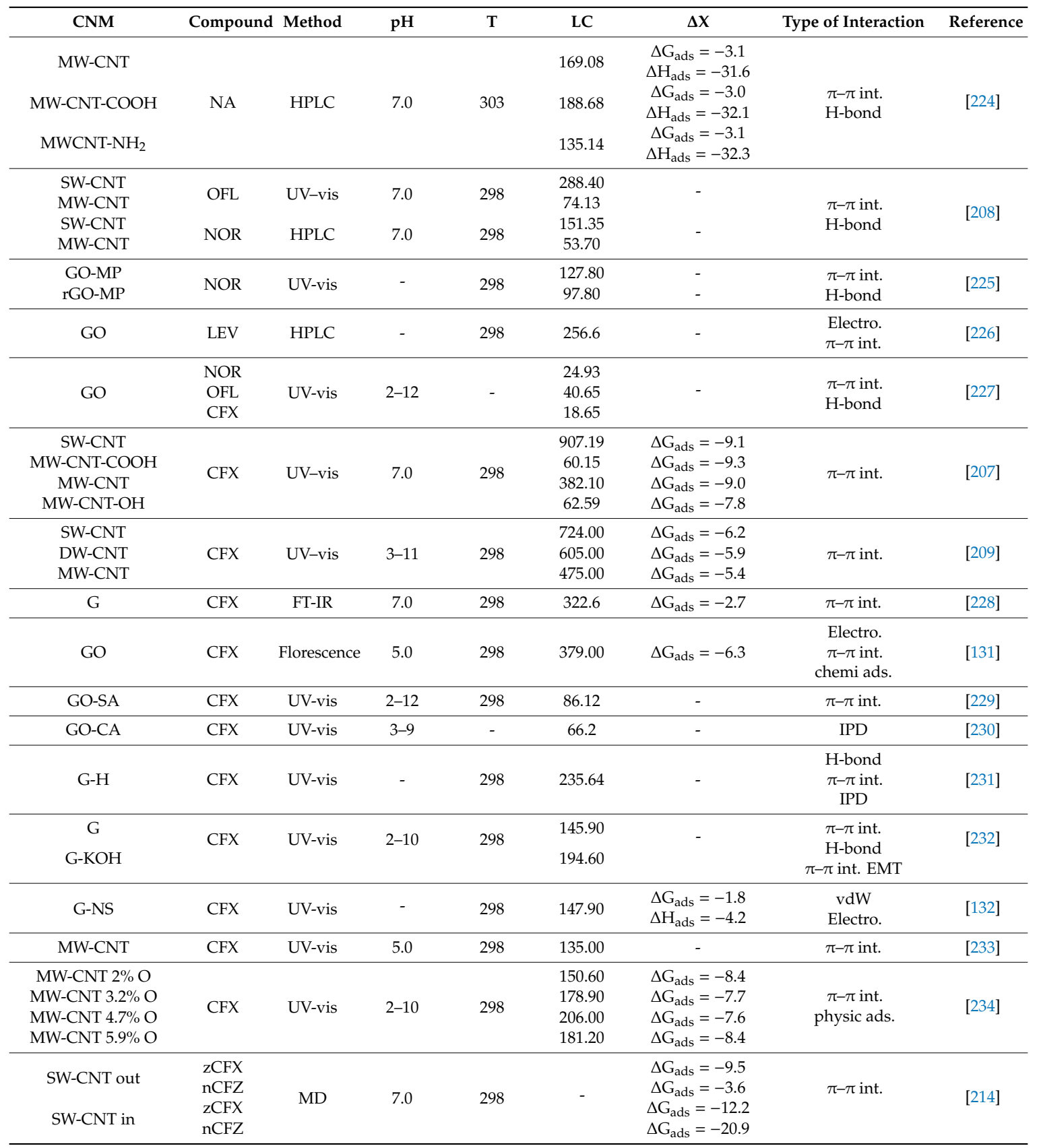


Experiments conducted on the removal of CFX and oxytetracycline (OXY) (Figure 9) by SW-CNTs, double-walled (DW-CNTs) and MW-CNTs agglomerates [209] revealed a moderate increase in adsorption between $\mathrm{pH} 3$ and 7, in particular the LC values, for SW-CNT and DW-CNT, while MWCNTs, the $\mathrm{pH}$ did not influence the removal process over the range 3-9 for MW-CNT. The highest removal capacities were registered using SW-CNTs as characterized by the higher value of LC found.<smiles>CN(C)[C@H]1C(O)=C(C(N)=O)C(=O)[C@]2(O)C(O)=C3C(=O)c4c(O)cccc4[C@@H](O)[C@@]3(C)C[C@H]12</smiles>

Tetracycline (TC)<smiles>CN(C)[C@H]1C(O)=C(C(N)=O)C(=O)[C@]2(O)C(O)=C3C(=O)c4c(O)cccc4[C@@](C)(O)[C@H]3[C@H](O)[C@H]12</smiles>

Oxytetracycline (OC)<smiles>CN(C)[C@H]1C(O)=C(C(N)=O)C(=O)[C@]2(O)C(O)=C3C(=O)c4c(O)ccc(Cl)c4[C@@H](O)[C@@]3(C)C[C@H]12</smiles>

Chlortetracycline (CC)

Figure 9. Tetracyclines commonly used in human medicine.

Several computational works related to the interactions between CFX and CNT are present in the literature $[132,136,207,214,217]$. A comparative experimental/theoretical investigation on the interaction between some antibiotics (norfloxacin (NOR), sulfadiazine (SDZ), tetracycline (TC)) and graphene-based material (GO and rGO) have been carried out by Zhang et al. [225]. The experimental results showed that the optimal adsorption $\mathrm{pHs}$ for NOR, SDZ, and TC are 6.2, 4.0, and 4.0, respectively; moreover, the adsorption of NOR is favored on rGOs while SDZ preferred GOs. They concluded that carboxylic groups of GO and rGO exert an electrostatic attraction with NOR and TC, but not with SDZ. DFT calculations were used to clarify the interactions between antibiotics and the two graphene-based materials characterized by a different percentage of $\mathrm{sp}^{2}$ and $\mathrm{sp}^{3}$ regions. The presence of $\mathrm{sp}^{3}$ carbons on the surface is due to chemical modification that introduces the presence of functionals groups which alter the conjugated structure. The results showed that both forms of $\mathrm{NOR}\left(\mathrm{H}_{2} \mathrm{NOR}^{+}\right.$and $\left.z \mathrm{NOR}\right)$ interact via H-bonds with the $\mathrm{sp}^{3}$ region, while, when attached to the $\mathrm{sp}^{2}$ region, the $\pi-\pi$ interactions dominate. The obtained $\mathrm{E}_{\mathrm{ads}}$ for $\mathrm{sp}^{2}-\mathrm{NOR}$ cluster are higher than for $\mathrm{sp}^{3}-\mathrm{NOR}$ cluster, which explains higher adsorption capacities of rGOs, which is characterized by larger amounts of $\mathrm{sp}^{2}$ regions. Similar interactions have been observed for SDZ: however, a larger binding energy is found for $\mathrm{sp}^{3}$ region in line with the predominant role of H-bonds and the higher adsorption amount found for SDZ on GO. For the cationic form of TC, adsorption is favorable in $\mathrm{sp}^{3}$ regions with the formation of $\mathrm{H}$-bonds, while neutral forms prefer $\mathrm{sp}^{2}$ regions and $\pi-\pi$ type interactions. The two opposite effects lead to the similar adsorption amount of GO and rGO at the optimal $\mathrm{pH}$ [225].

In another study [132], CFX adsorption capacity on graphene reached a maximum at $\mathrm{pH}=6.0$ and occurs in the physisorption regime. Adsorption of CFX, NOR, and OFL, on GO were studied by experimental methods and DFT calculations [227]. CFX and NOR present the maximum adsorption at $\mathrm{pH}=7.0$, while for OFL at $\mathrm{pH}=4.0$. DFT calculations reveal that $\pi-\pi$ interactions induce an orientation of the FQs parallel to the GO plane, but it is not the most stable configuration found. Strong $\mathrm{H}$-bonds between FQs and oxygen group of $\mathrm{GO}$ are instead established and are accompanied by an exothermic process.

The heat-driven desorption process of CFX from a SW-CNT was studied by MD simulations [217] to explore the potential application of CNTs as drug carrier, where the adsorbed drug molecule is later released by near-infrared radiation heating [235]. 
The CFX molecules were found to remain initially mostly confined inside the SW-CNT with a low diffusion coefficient. This suggested that the storage of CFX molecules inside the SW-CNT is feasible. Results indicate that SW-CNT heating by NIR radiation can potentially be used for effective drug release thank to the fast ( $<10 \mathrm{ps)}$ vibrational energy transfer among SW-CNT, water, and CFX which increases the diffusion coefficient of the latter by a factor of 5-7. However, it should be underlined that in the work of Chaban V.V. et al. [217] only nHCFX was considered which, at physiological pH, is only a small fraction of the total species (Figure 8c).

Both neutral and zwitterionic form of CFX remain adsorbed parallel to the SW-CNT surface interacting via $\pi-\pi$ stacking [214]. However, when multiple molecules are presents, other arrangements are observed due to CFX-CFX interactions which allow the formation of stacked structures ("sandwich-like") in the confined space inside the SW-CNT [214]. The calculation of the Eads suggests a preferential adsorption on the internal wall of the SW-CNT. This is also confirmed by the calculation of the adsorption Gibbs free energy $\left(\Delta G_{\text {ads }}\right)$. Negative $\Delta G_{\text {ads }}$ show that $C F X$ adsorption is a spontaneous process on both sides of the wall, even if more favorable on the inner surface. The $\Delta G_{\text {ads }}$ were in good agreement with the experimental values as can be observed in Table 1.

The $\mathrm{E}_{\mathrm{ads}}$ for the CFX-SW-CNT adducts are significantly more negative than the obtained $\Delta \mathrm{G}_{\mathrm{ads}}$. This suggested a strong contribution of desolvation upon adsorption as indicated by net decrease of the number of water molecules released upon adsorption [214].

\subsection{Other Antimicrobials}

Tetracycline (TC) (Figure 9) is the second most used antimicrobial worldwide [236]. It exhibits broad-spectrum antibacterial activities by blocking DNA replication enzymes and inhibiting bacterial growth [237]. TC has a planar structure consisting of four fused rings with hydrophilic groups on one face, hydrophobic groups on the other face and each ring including phenol, alcohol, ketone and amino [236]. In recent years TC has raised a serious environmental concern, as incompletely metabolized TC has been detected in wastewater treatment plants and soils $[102,238]$. Hence, the removal of TC is of great interest as evidenced by the number of experimental works related to the adsorption of TC on carbon-based materials [127,136,211,215,225,239-242]. In Table 2 available experimental data related to the adsorption of TC and other antimicrobials on different CNMs are reported.

Also in this case, negative $\Delta \mathrm{G}_{\mathrm{ads}}$ values are observed which depend on the type of molecule adsorbed by the adsorbent material and the pH. Ghadim et al. [211] studied the adsorption and release of TC onto GO from an experimental and theoretical point of view and found that tetracycline strongly binds to GO surface via $\pi-\pi$ and cation $-\pi$ interaction. Thermodynamic parameters obtained showed positive $\Delta H$ and negative $\Delta G$ indicating that the adsorption process was entropy-driven. MD simulations showed the presence of $\pi-\pi$ stacking interactions between tetracycline and graphene's surface which results in an equilibrium distribution between bound and free compound.

Another experimental/theoretical DFT study [127] on the competitive interactions of TC and sulfamethazine (SMZ, Figure 8) on reduced graphene oxides showed some cooperative effect due to co-adsorption. Several techniques (scanning electron microscope (SEM), FT-IR, UV-Vis and XPS) revealed that the highly efficient sorption of TC and SMZ on rGOs was mainly due to the $\pi-\pi$ interaction and cation- $\pi$ interactions, high surface energy sites derived from defects, edges and groove areas [127].

The $\mathrm{E}_{\mathrm{ads}}$, for TC resulted to be higher than that for SMZ, indicating that TC have a higher affinity to $\mathrm{rGO}$ than SMZ. Adsorption and dynamics of TC, oxytetracycline (OC), and chlortetracycline (CC) (Figure 9) on rGO and GO surface were investigated by DFT calculations and MD simulations [218].

DFT calculations showed that the $\pi-\pi$ interaction and H-bond play significant roles when TCs adsorbed on graphene materials. Moreover, the authors proposed that weaker $\mathrm{C}-\mathrm{H} \cdots \pi$ interaction might contribute to the adsorption mechanism. Additionally, the effects of the $\mathrm{pH}$ on the adsorption process was investigated and it emerged that low $\mathrm{pH}$ values were suitable for the adsorption of TCs on these materials due to the reinforced $\pi-\pi$ interaction, $\mathrm{H}$-bonds and cation $-\pi$ interaction. The calculation of the $\mathrm{E}_{\mathrm{ads}}$ revealed that the adsorption affinity follows the order: $\mathrm{CC}>\mathrm{TC}>\mathrm{OC}$ and $\mathrm{TC}>\mathrm{CC}>\mathrm{OC}$ 
in the GO and rGO systems, respectively. In addition, the adsorption efficiency was higher when the $\mathrm{pH}$ of the solution was lower and when less polar solvent environments are present.

A comparative study on TC adsorption by graphite, GO, rGO and MW-CNT was carried out by $\mathrm{He}$ et al. [215]. The experimental results revealed that adsorption capacity followed the order: $\mathrm{GO}>\mathrm{rGO}>\mathrm{MW}-\mathrm{CNT}>$ graphite. DFT calculations indicated that the oxygen functional groups on GO reduced its $\pi$-electron-donating ability, indeed higher HOMO (highest occupied molecule orbital) energy corresponded to higher $\pi$-electron-donating ability $[243,244]$; rGO had the highest HOMO energy, showing the highest $\pi$-electron-donating ability. Nevertheless, the presence of oxygen-containing functional groups decreased the HOMO energy of GO. Accordingly, $\pi-\pi$ interactions between GO and tetracycline were weakened as a result of the decreased $\pi$-electron-donating ability of GO surface. The comparison of adsorption efficiency at different $\mathrm{pH}$ indicated that electrostatic interaction also played an important role in TC-GO interactions. Site energy analysis, the difference of sorption energies between the solute and solvent for a given sorption site, confirmed a highly heterogeneous distribution of the binding sites and strong TC binding affinity of GO surface.

Table 2. Some experimental adsorption parameters of TC and other antimicrobials drugs on CNMs $\left(\mathrm{T}(\mathrm{K}), \mathrm{LC}\left(\mathrm{mg} \mathrm{g}^{-1}\right), \Delta \mathrm{X}, \mathrm{kcal} \mathrm{mol}^{-1}\right)$. Sulfadiazine (SDZ), sulfamethazine (SMZ), sulfadimethoxine (SDM), sulfamethizole (SMT), sulfamethoxazole (SMX).

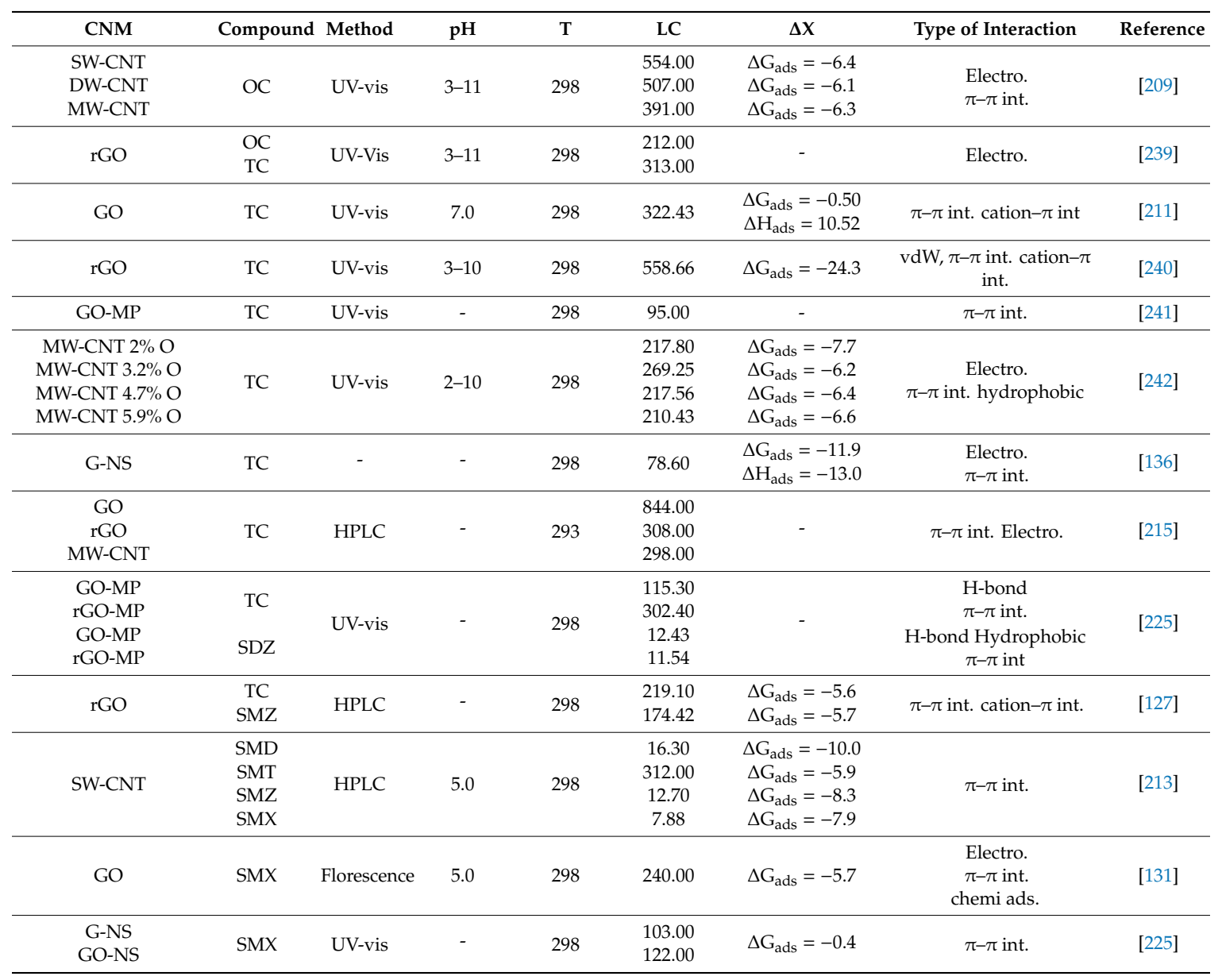

Electrostatic and $\pi-\pi$ interactions were shown to be at the origin of an efficient TC adsorption on a graphene nano-sheet (G-NS) [136]. Experimental, quantum mechanical semi-empirical method (neglect of diatomic differential overlap (NDDO) and Austin Model 1 (AM1)) and MD simulations at two different temperatures 298.15 and $318.15 \mathrm{~K}$ were carried out. MD simulations showed that vdW interaction energy at $298.15 \mathrm{~K}$ reaches equilibrium state in $\sim 0.2 \mathrm{~ns}$ while at $318.15 \mathrm{~K}$, the vdW energy is 
stable in $\sim 1$ ns. Moreover, the values of vdW energy at $298.15 \mathrm{~K}$ is more negative than $318.15 \mathrm{~K}$, indeed the distance between TC and G-NS increased at higher temperatures (more molecular vibrations); indicated that the optimal temperature for the adsorption was $298.15 \mathrm{~K}$.

Sulfonamides are antimicrobials largely used in human and veterinary medicine $[245,246]$ and their metabolic products are frequently detected in wastewater, surface water and ground water [210]. SW-CNTs were studied as adsorbents for this class of antimicrobials, in particular the effect of different oxygen-containing surface functional groups on adsorption of sulfamethazine (SMZ), sulfadimethoxine (SDM), sulfamethizole (SMT), sulfamethoxazole (SMX) (Figure 10) [213] was investigated.<smiles>Cc1cc(C)nc(NS(=O)(=O)c2ccc(N)cc2)n1</smiles>

Sulfamethazine (SMZ)<smiles>Cc1nnc(NS(=O)(=O)c2ccc(N)cc2)s1</smiles>

Sulfamethizole (SMT)<smiles>COc1cc(NS(=O)(=O)c2ccc(N)cc2)nc(OC)n1</smiles>

Sulfadimethoxine (SMD)<smiles>Cc1cc(NS(=O)(=O)c2ccc(N)cc2)no1</smiles>

Figure 10. Sulfanilamides commonly used in human medicine.

Experimental results indicated that adsorption capacity increases with the decreasing in oxidation degree of SW-CNTs, and follows the order of SDM > SMT > SMZ > SMX. The predominant adsorption mechanisms are related to the $\pi-\pi$ between the heterocyclic rings in sulfonamides and the benzene-type rings of SW-CNTs. DFT calculations revealed that the oxygen group presents on the SW-CNT surface inhibited the sulfonamides adsorption, and this effect follows the order $-\mathrm{COO}->-\mathrm{C}=\mathrm{O}>\mathrm{COC}$. Moreover, $-\mathrm{COO}-$ and $-\mathrm{C}=\mathrm{O}$ groups located on the center of SW-CNTs, damage the conjugated structure of benzene-type ring, consequently, defects appeared on the surface in excellent agreement with the TEM data. These defects reduce the possibility of $\pi-\pi$ interactions between sulfonamides and SW-CNT and the interaction results to be weaker. However, when the functional groups (-OH and -COC-) were placed on the terminal atoms of the SW-CNT the conjugated structure of rings was not affected.

The combination of different compounds (lincomycin hydrochloride (LMH), chloramphenicol (CPC) and gentamycin sulfate (GMS) (Figure 11) with GO was proposed [216] with the aim to obtain a synergistic effect in the antibacterial activity. The combination of GO with different antibiotics provided different extents of antibacterial efficiency. DFT calculations employing plane wave approach revealed that GO presents higher $\mathrm{E}_{\text {ads }}$ for GMS than CPC and LMH, indicating that the desorption capacity of the three antibiotics follows the order: $\mathrm{LMH}>\mathrm{CPC}>\mathrm{GMS}$. According to these results, GO could adsorb antibiotics with a strength depending on the number of aromatic rings and on the presence of different functional groups in the antibiotics. The authors assigned [216] the increased microbial inhibition ability found for the $\mathrm{LMH} / \mathrm{GO}$ combination to the lowest calculated $\mathrm{E}_{\mathrm{ads}}$. As a consequence, $\mathrm{LMH}$ becomes the most effective among the three antibiotics, as it is the easiest to desorb from GO. 


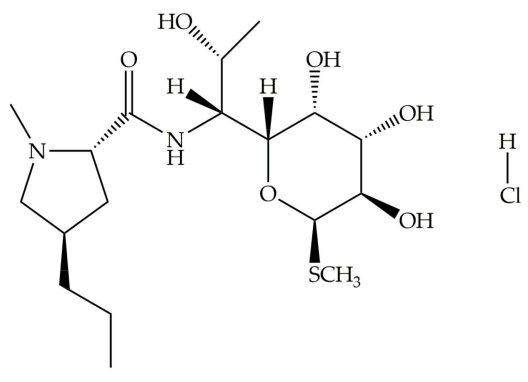

Lincomycin Hydrochloride (LMH)

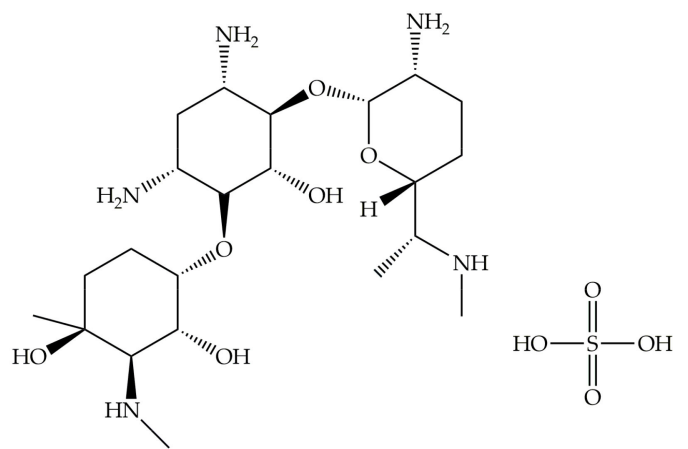

Gentamycin Sulfate (GMS)<smiles>O=C(N[C@@H](CO)[C@H](O)c1ccc([N+](=O)[O-])cc1)C(Cl)Cl</smiles>

Figure 11. Lincomycin hydrochloride, chloramphenicol and gentamycin sulfate antimicrobial agents.

\section{Cytostatic Compounds}

The use of nanocarriers such as carbon-based materials has been shown to improve the pharmacological properties of traditional chemotherapeutics [247,248], the main advantages of using nano-particles relate to their ability to target tumor tissue in an active or passive approach $[49,248,249]$. Most of the conventional chemotherapeutic agents have poor pharmacokinetics and are distributed non-specifically in the body, thus leading to severe side-effects and decrease of efficacy. For these reasons, the targeted transport of a drug is highly desirable and nano-carriers can improve the delivery to a tumor either passively through the vasculature surrounding the tumors (enhanced permeability and retention effect) or by active targeting of overexpressed receptors of cancer cells [250]. CNMs could also represent a good option for their removal from wastewaters [251]. Indeed, cytostatic drugs are usually found in hospitals or manufacturing plants wastewaters in the ppb range [251]. Despite these concentrations are quite low, the effect of chronical exposure of living organisms to low dosages is unknown and the efficiency of conventional water treatment plants in their degradation is uncertain.

\subsection{Platinum Anticancer Compounds}

Fifty years after its discovery, cisplatin (Figure 12) is still one of the most used drugs in chemotherapy [252]. To overcome its limitations (high toxicity, tumor resistance), other platinum drugs have also been developed (Figure 12). The accepted mechanism of action [253] of such compounds consists in two stages: (i) intracellular activation by the hydrolysis of the ligand; (ii) formation of intra-strand cross-links in DNA through the covalent binding of the Pt complex to purine bases. The result is a bent DNA that causes the generation of defective proteins and ultimately leads to cell death. Despite the high efficacy, these compounds present several serious side-effects and acquired or intrinsic resistance of tumors [253].

The use of nano-carriers has been proposed as one of the possible strategies to resolve the drawbacks of platinum-based drugs and to reduce the systemic dose while increasing the amount of active molecule reaching the target site [248,254-256]. Numerous experimental and theoretical studies (as an example see [257-263] and references therein) were directed either at describing the reactivity of such compounds as well as the interactions with nanocarriers $[57,125,264-271]$. 
<smiles>N[P+](N)(Cl)Cl</smiles>

Cisplatin

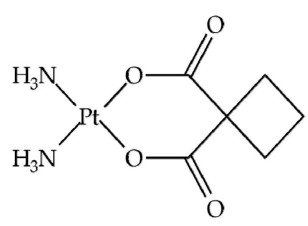

Carboplatin

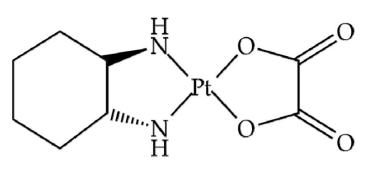

Oxaliplatin

Figure 12. Platinum anticancer drugs approved worldwide.

Ajima et al. [266] studied the interaction between cisplatin and a SW-carbon nanohorns (SW-CNH): cisplatin was incorporated inside the SW-CNH and about $70 \%$ of the load was released by SW-CNH when they presented holes with hydrogen-terminated edges. When SW-CNH presented holes with oxygen-containing functional groups only $15 \%$ of cisplatin was released. The release of cisplatin from a SW-CNH in vitro and in in vivo experiment was also studied [265] and it was shown that solvent is an important factor influencing the incorporation process of cisplatin on SW-CNH: indeed, the use of water instead of DMF increased the quantity of cisplatin incorporated from the $15 \%$ up to $46 \%$. Moreover, the release of cisplatin was slow, in agreement with previous studies [266], but the total released quantity increased from previous 60 to $100 \%$ [266]. in vitro experiment, the anticancer efficiency of cisplatin-SW-CNH complex increased to $4 \div 6$ times greater than that of the free cisplatin. The enhancement of anticancer efficiency was realized by the adherence of SW-CNH to the cells, which would increase the local concentration of cisplatin leading to effective cell killing. Similar results have been obtained also in vivo experiment; the cisplatin-SW-CNH suppressed the tumor growth more than free cisplatin in mice. The cisplatin-SW-CNH complex stayed in the tumor tissues for a considerable period, up to 25 days, which contributed to the higher anticancer efficiency compared to the drug alone. The interaction between $\mathrm{CNH}$ and cisplatin has been investigated by MD simulations [272]: it was found that when the drug is absent, the $\mathrm{CNH}$ contains on average 36 water molecules, while when cisplatin is included most of water molecules were expelled out to the bulk. The calculated binding free energy indicated that the inclusion of the cisplatin inside the $\mathrm{CNH}$ was thermodynamically favorable in water, mostly due to van der Waals and electrostatic interactions.

The covalent interaction between cisplatin and GO functionalized with polyethylene glycol (PEG, GO-PEG) was investigated in vitro against several cell lines [270]. Cisplatin-GO-PEG system demonstrated a controlled in vitro release of the drug and exhibited remarkable toxicity to MCF-7 and CAL-27 cells and the drug vehicle resulted nontoxic.

The FT-IR and TEM investigation of interaction between cisplatin and functionalized MW-CNT with carboxyl (-COOH) group proved that the surface of MW-CNTs is coated with cisplatin and that the release of platinum is higher from functionalized MW- CNTs than MW-CNTs [271].

Cisplatin was also loaded on GO with two regulatory sequences, BRCA1 (Breast Cancer Type 1 susceptibility protein) and BRCA2 (Breast Cancer Type 2 susceptibility protein), synthesized from ssDNA [268]: the efficiency of GO-cisplatin complex in quenching of the sequence synthesized was significantly reduced compared to cisplatin [268].

Fullerene $\mathrm{C}_{60}$ was loaded with cisplatin in in physiological solution $(0.9 \% \mathrm{NaCl})$ [273] to determine the mechanism by which this mixture can potentially exert a biological synergy. Two type of structures was found: (i) the island-like growth was obtained by the deposition of cisplatin from physiological solution, (ii) the filament-like nanostructures was acquired by deposition from the mixture of fullerene with cisplatin in the same solution. The isothermal titration calorimetry (ITC) showed that the complexation had a purely entropic character. Finally, DFT calculations confirmed the stability of these complexes. As far as carboplatin is concerned, adsorption and desorption on MW-CNT was experimentally studied [267]: carboplatin-filled MW-CNTs in vitro inhibited growth of bladder cancer cells whereas, unfilled, open MW-CNTs barely affected cancer cell growth.

In summary, all CNMs cisplatin system demonstrated higher in vitro activity than cisplatin alone: also, in vivo testing showed that, cisplatin-CNMs systems, in particular SW-CNH, had higher 
anticancer effect than the free cisplatin $[57,265,266,274]$. However, it seems that also CNMs had certain anticancer effects compared to simple saline injection [265].

The interaction between platinum-based drugs and CNM has been extensively studied also from a theoretical point of view [273,275-285]. DFT calculations showed formation of a stable complex between $\mathrm{CNH}$ and cisplatin [275], moreover the calculated NMR (Nuclear Magnetic Resonance) chemical shifts $\left({ }^{1} \mathrm{H}\right.$ and $\left.{ }^{15} \mathrm{~N}\right)$ exhibits a shift of $\sim 20$ ppm when cisplatin was adsorbed to $\mathrm{CNH}$ that was experimentally checked. Similar results were observed when CNH was replaced by SW-CNT [276] or oxidized SW-CNT [278]. The inclusion of cisplatin on SW-CNT was found to be energetically favorable $\left(E_{\text {ads }}=-5.0 \mathrm{kcal} \mathrm{mol}^{-1}\right)$ [277]. Moreover, calculated Raman spectra showed a decrease of the wavenumber in the spectral range of the radial breathing modes with the insertion of the cisplatin molecules in excellent agreement with experimental data [277]. Capped and opened SW-CNTs of different diameters can also adsorb strongly cisplatin [285], as revealed by DFT calculations, which showed that the parallel orientation relative to SW-CNT surface was preferred. Binding energies are dependent on SW-CNT curvature. Moreover, cisplatin changes shape when encapsulated into $\mathrm{CNTs}^{\prime}$ whose diameters are less than $7.6 \AA$ and it is destroyed when placed into the narrowest CNT $(8,0)$ with the formation of $\mathrm{Pt}_{1} \mathrm{Cl}_{2}$ and $\mathrm{N}_{2} \mathrm{H}_{5} \cdots \mathrm{H} \cdots \mathrm{CNT}(8,0)$. The simulated ${ }^{195} \mathrm{Pt}-\mathrm{NMR}$ spectra reveal that Pt chemical shift is sensitive to SW-CNT's diameter and is linearly correlated to confinement energies: ${ }^{195} \mathrm{Pt}-\mathrm{NMR}$ could be a useful technique to control the amount of cisplatin loaded in SW-CNTs [285].

The interaction between cisplatin and graphene prototypes was studied in detail using DFT-symmetry adapted perturbation theory (DFT-SAPT) and second order Møller-Plesset perturbation theory (MP2) calculations [279]. The dispersion corrected MP2 (MP2C) potential energy surface scan of the cisplatin-pyrene dimer distance revealed that parallel orientations showed the strongest interaction (as also found by Hosni Z. et al. [285]). These calculations were used as reference data to validate different DFT levels: the best DFT functional reproducing MP2C energy resulted to be PBE-D3(BJ) [160,190-192] while poor results were obtained with pure PBE [190-192], B3LYP [286], B3LYP-(D3(BJ)) [160,286] and M06-2X $[186,187]$ functionals, which account for different percentages of Hartree-Fock exchange. In particular, the B3LYP and PBE underestimate the reference MP2C energy profiles. The inclusion of the dispersion correction leads to better agreement with the reference MP2C energy profiles although the B3LYP-(D3(BJ)) provides a systematic overestimation. The M062X functional display a systematic underestimation of the reference MP2C energy profiles. The best functional was finally used to study the interaction between cisplatin and larger graphene prototypes, in particular ovalene $\left(\mathrm{C}_{32} \mathrm{H}_{14}\right)$, as $\mathrm{t}$ represents a good compromise between computational cost and accuracy. Moreover, the adsorption enthalpy of cisplatin on graphene prototype was particularly favorable $\left(\sim-20 \mathrm{kcal} \mathrm{mol}^{-1}\right)$ being twice that estimated for the corresponding benzene adsorption.

A "carbon nanotube bottle" (CNB) built by capping a MW-CNT with gold nanoparticles [57] showed a higher drug loading in respect to open SW-CNT reported in literature [274]. Such carriers were shown to deliver cisplatin to cells under physiological conditions. Approximately $89 \%$ and $93 \%$ of encapsulated cisplatin was released at $\mathrm{pH} 7.4$ and 5.5 during $6 \mathrm{~h}$, respectively in agreement with literature data [274], in which drug release is reported after $48 \mathrm{~h}$. The kinetics of release of cisplatin from MW-CNT capped by magnetic nanoparticles (MNP) was studied by MD simulations and experimentally [280]. When the MNP are detached from the nanotube tips, the initially encapsulated cisplatin molecules diffuse out of the nano-tube interior. The release of cisplatin was found to be an activated process with the activation barrier of $6 \mathrm{kcal} \mathrm{mol}^{-1}$ in this ideal system where, however by experimental point of view, this activation energy is $\sim 20 \mathrm{kcal} \mathrm{mol}^{-1}$ [57]. This discrepancy can be attributed to the existence of numerous surface defects in the case of experimental system. Similar discrepancy was also found for the release of cisplatin calculated by Ficks equation: it predicts that release is completed in few milliseconds while the experiment shows that the process is much slower $(\sim 3 \mathrm{~h})$ [280]. The study on the stability of these carbon nano-containers (MW-CNT-MNP) in water revealed that it depends on the direction of the collision and the MW-CNT-MNP are always stable and the intermolecular collisions do not lead to leakage of drug molecules [281]. The estimated range of intermolecular 
interactions suggests that the current architecture of the nano-containers is unstable in terms of colloidal stability. Further functionalization of nano-tubes sidewalls is necessary in order to reduce strong hydrophobic interactions between nano-containers [281]. The optimization of nano-containers based on MW-CNT capped with magnetic nano-particles by surface functionalization was then evaluated by MD simulations [282]. Surface modifications proposed were: adsorption of colloid nano-particles; covalent functionalization of polar amide groups. These differently modified sidewalls provided distinct energy profiles associated to the decapping/capping processes. The non-covalent approach turned out to be too weak to make the whole system stable for a long time and resulted not to be preferred in the design of magnetically triggered drug delivery systems. On the contrary, covalent modification provided the required energetic balance between the capped and uncapped forms.

MD simulations were also employed to study the diffusion of a cisplatin-loaded SW-CNT through a cell membrane [283]. Free energy profiles of the diffusion of SW-CNT with several cisplatin molecules adsorbed inside were obtained. Moreover, the simulation indicated the release of cisplatin near the cell membrane model is extremely rapid. The first molecules were released in $2.5 \mathrm{~ns}$ while the second one in 5.3 ns. The authors explain this rapid extraction by the nanocarrier solvation. The SW-CNT diffuses easily close to the lipid bilayer due to its hydrophobicity, and the water molecules are progressively released, allowing the cisplatin molecules to exit.

The delivery of cisplatin from different type of NTs such as carbon, boron nitride and silicon carbide forced by Ag-nano-wire was studied by MD simulations to understand the effects of diameter, chirality, and composition of the nano-tube [284]. Results indicated that NT composition and diameter are more important than the chirality and temperature of the system. The composition plays an important role; silicon carbide NTs have the lowest efficiency for drug release, due to their stronger interaction with the drug. Moreover, the release process is mainly thermodynamically controlled rather than kinetically controlled (i.e., no energetic barriers for the release process are found).

\subsection{Doxorubicin}

Doxorubicin (DOX) (Figure 13) is a widely used anticancer drug that belongs to a class of compounds with similar structures, called anthracyclines [287]. DOX has shown great efficacy in killing cancer cells for in solid and liquid tumors. This molecule presents two confirmed mechanisms of action: (i) intercalation into DNA bases with consequent inhibitions of the topoisomerase-II enzyme, (ii) generation of free radicals, causing oxidative damage to cellular membranes, proteins and DNA [287]. However in spite of the antitumor activity, DOX presents several undesired side effects [288-290] and the use of nanocarriers could improve its pharmacological properties. For this reason, interaction between DOX and carbon-based materials have been subject of numerous studies $[101,137,291-297]$ in order to assess their application as nanocarriers.<smiles>COc1cccc2c1C(=O)c1c(O)c3c(c(O)c1C2=O)C[C@@](O)(C(=O)CO)C[C@@H]3O[C@H]1C[C@H](N)[C@@H](O)[C@H](C)O1</smiles>

Doxorubicin (DOX)

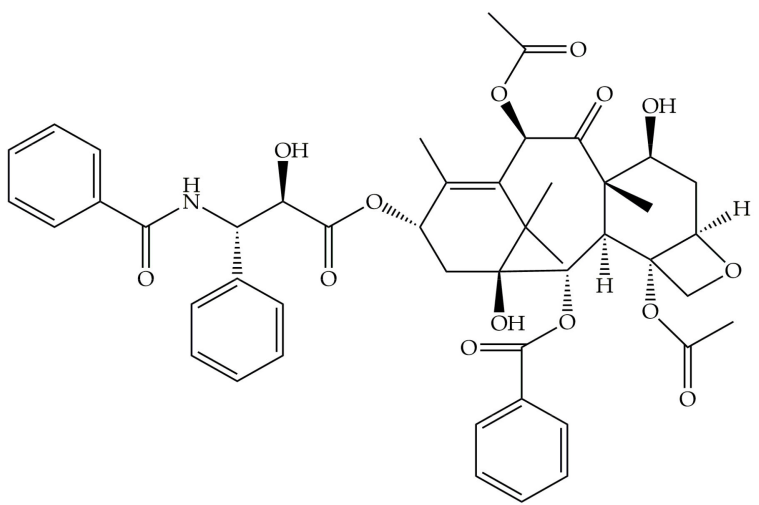

Paclitaxel (PAX)

Figure 13. Doxorubicin and paclitaxel anticancer drugs. 
The adsorption and desorption of DOX on oxidized MW-CNT indicated a high LC of this material even though the process was quite slow [293]. In the same work, the desorption process was shown to be $\mathrm{pH}$ dependent, and at $\mathrm{pH} 7.4$ this process occurred in very small quantities, while at $\mathrm{pH}=5.5$ an increase in the quantity of desorbed DOX was observed. The presence of serum proteins facilitated the desorption of DOX significantly thanks to the formation of strong bond with oxidized MW-CNT with an occupation of the surface.

DOX resulted to be efficiently adsorbed by GO following a Langmuir isotherm with a maximum LC of $1428.57 \mathrm{mg} \mathrm{g}^{-1}$, kinetics fits to a PSO model [295]. Moreover, it was found that adsorption was spontaneous and endothermic, thus also in this case the process was entropy-driven. The same authors [296] studied the cytotoxicity of GO and GO-DOX on human multiple myeloma cells. The results showed that GO-DOX system significantly inhibited cell proliferation as compared with pure DOX. Moreover, the authors found that GO caused low cytotoxicity and did not affect the antitumor activity of DOX. In conclusion, GO seemed to be suitable as nano-carrier for an anticancer drug with potential use to treat hematological malignancies.

The adsorption of DOX on PEG-functionalized MW-CNTs (MW-CNT-PEG) was investigated by Farahani et al. [137]. Contrarily to the GO-DOX system [295], adsorption, which followed a PSO kinetics, is better described by the Freundlich model, suggesting the presence of an heterogeneous nature of the interaction sites. The release of DOX from MW-CNT-PEG was pH dependent and the release rate was much higher at pH 5.5 than that at pH 7.4 in agreement findings in Wang Y. et al. [293].

Adsorption on GO was characterized using transition electron microscopy, zeta potential, Raman spectroscopy, UV-vis spectroscopy, and FT-IR spectroscopy [101]. The authors showed that the optimized $\mathrm{pH}$ and temperature to load a largest amount of DOX was 7.8 and $309 \mathrm{~K}$.

MD simulations were employed to study DOX adsorption on functionalized SW-CNT in water [298]: DOX could be entrapped within the CNT, attachment to the sidewall of the SW-CNT, and adsorption on the SW-CNT inner cavity. Simulation results indicated that Langmuir isotherm could predict the adsorption behavior more accurately than Freundlich one [298].

MD simulation of the adsorption process of DOX onto graphene and GO showed that the interaction becomes stronger with the increase of the surface density of oxygens [299]. The influence of $\mathrm{pH}$ on the DOX interactions resulted to be negligible in acidic or neutral conditions, while more significant interactions occurred at basic $\mathrm{pH}$ and in the presence of a certain oxygen density to carbon $(\mathrm{O} / \mathrm{C})$ ratios of 1:6 and 1:3. Moreover, the adsorption and release of 24 DOX molecules on the GO surface at variable $\mathrm{pH}$ were simulated, showed that $\mathrm{pH}=7$ is optimal for loading while $\mathrm{pH}=5$ is better for drug release [299].

MD simulations were also useful for studying the adsorption of DOX and functionalized graphene, in particular comparing hydroxyl $(-\mathrm{OH})$, carboxyl $(-\mathrm{COOH})$, methyl $\left(-\mathrm{CH}_{3}\right)$ and amine $\left(-\mathrm{NH}_{2}\right)$ groups [300]. The results showed that G-COOH adsorbed DOX more effectively in comparison to other functionalized graphene thanks to a higher binding energy.

A recent MD work where DOX adsorption on SW-CNT was studied [301] provided several interesting conclusions: (i) armchair, zig-zag and chiral nano-tubes with a $14 \AA$ diameter present optimal DOX-SW-CNT interactions; (ii) the encapsulated DOX interacts more strongly with the SW-CNT (as also found for other drugs) [214]); (iii) the presence of bumpy defects on the SW-CNT influence the DOX-SW-CNT interactions, depending on the SW-CNT chirality; (iv) PEG functionalization favors interactions with DOX; $(v)$ formation of a double $\pi-\pi$ interactions of the encapsulated DOX can be established, depending on the SW-CNT diameter; (vi) DOX-SW-CNT interactions can induce deformation of the SW-CNT.

Adsorption and encapsulation of DOX on covalently functionalized SW-CNT was studied by MD simulations and DFT calculations [302]: functionalization seemed to increase the LC of SW-CNT; moreover, LC was increased when the DOX molecules were non-protonated. It was concluded that, intersection of carboxyl and amine functionalization can be used to design a $\mathrm{pH}$ sensitive drug carrier 
where their protonation in acidic condition can decrease the electrostatic interactions of the loaded drug with the functionalized SW-CNT and as a result can promote the drug release.

DFT and ab-initio MD simulations were employed also to study the adsorption of DOX also on graphene [303] and a binding energy of $\sim 11.5 \mathrm{kcal} \mathrm{mol}^{-1}$ was found for the most stable configuration.

The interaction between DOX and graphene or GO was studied using experiments and DFT calculations [304]. Results showed that graphene is a better support for DOX in respect to GO thank to the formation of strong $\pi-\pi$ stacking interactions. Moreover, DOX has been placed in the two type of region the $\mathrm{sp}^{2}$ and $\mathrm{sp}^{3}$ region (due to the presence of $\mathrm{O}$ and $\mathrm{OH}$ group). The calculations showed that DOX interacts stronger with $\mathrm{sp}^{2}$ region than $\mathrm{sp}^{3}$ region where the binding site is characterized by $\pi-\pi$ and H-bonding interactions, respectively.

\subsection{Paclitaxel}

Paclitaxel (PAX, Figure 13) is an anticancer drug targeting $\beta$-tubulin and interferes with the cancer cell division process by inducing cell cycle arrest and the programmed cell death [305]. Recently, numerous studies were aimed at developing nano-carriers to deliver PAX to overcome its major drawbacks (low solubility, diffusion from cells and side effects) [306]. Some examples include PAX conjugation to PEG-coated SW-CNTs [307], loading through non-covalent interactions to PEGylated hydrophobic carbon clusters which associates to an antibody to obtain a targeted delivery [308].

Rezaian et al. [309] studied the co-adsorption and release of DOX and PAX by SW-CNT, fullerene, and $\mathrm{GO}$ in combination with N-isopropylacrylamide. Results of MD simulations indicate that SW-CNT is a better carrier for the co-adsorption and co-release of DOX and PAX in respect to fullerene and GO.

The interaction between PAX and different graphene materials, such as graphene GO and functionalized GO with chitosan (GO-CS), was studied by MD simulations [310]. The interaction between PAX and graphene is stronger in respect to other system studied and the $\pi-\pi$ stacking and hydrophobic interactions are the main driving forces for the adsorption of the drug. For the GO-CS and GO, the main driving forces for the adsorption was the formation of $\mathrm{H}$-bond, and the number of $\mathrm{H}$-bond is higher in GO-CS than in GO, consequently chitosan in improving the adsorption of the drug onto nanomaterial. The same authors investigated adsorption mechanism of PAX on pristine and functionalized SW-CNT; three different type of group were investigated, in particular PEG, carboxyl group (-COOH) and amine group $\left(-\mathrm{NH}_{2}\right)$ [311]. In the latter system, PAX was adsorbed in non-functionalized SW-CNT through by $\pi-\pi$ interactions while polar interactions are the main driving forces for the adsorption on functionalized SW-CNT. The calculation of van der Waals energy and the number of contacts indicate that the PEG-SW-CNT system has the best performance in drug adsorption. Moreover, the functionalization increases the solubility of SW-CNT thanks to the formation of H-bonds between functional groups of SW-CNTs and water molecules.

Computational results showed that the PAX drug could be adsorbed by $\pi-\pi$ stacking in non-functionalized SW-CNT while polar interactions are the main driving forces for the adsorption on functionalized SW-CNT. The calculation of Van der Waals energy and the number of contacts indicate that the PEG-SW-CNT system has the best performance in drug adsorption. Moreover, the functionalization increases the solubility of SW-CNT thanks to the formation of H-bonds between functional groups of SW-CNTs and water molecules.

\subsection{Other Cytostatics}

Flutamide (FLU) (Figure 14) is a non-steroidal, synthetic, and antiandrogenic drug widely used in prostate cancer [312]. FLU was found to block the action of both endogenous and exogenous testosterone and, in addition, to be a potent inhibitor of testosterone-stimulated prostatic DNA synthesis. Moreover, it is capable of inhibiting prostatic nuclear uptake of androgen [313]. 
<smiles>Cc1ccc(NC(=O)C(C)C)cc1C</smiles>

Flutamide (FLU)<smiles>NC(=O)NO</smiles>

Hydroxyurea (HUR)

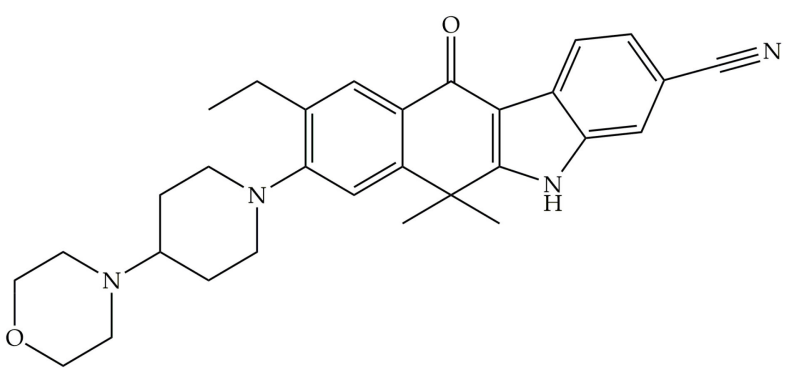

Alectinib (ACB)

Figure 14. Flutamide, hydroxyurea, alectinib anticancer agents.

Adsorption of FLU on SW-CNT's was studied by two articles of published by Kamel et al. [314,315]. In the first work [314] adsorption of FLU on SW-CNT was investigated by MD simulations and DFT calculation. The latter (employing B3LYP functional) calculations were carried in gas phase and water, represented by a polarized continuum (PCM) model [316]. The latter approach is one of the most currently employed continuum solvation methods [317] in quantum chemical calculations to introduce solvent effects. Solvent effect becomes important for accurate estimations of thermochemical and spectroscopic properties (see for example $[257,318,319]$ ). However, it should be underlined that with these methods H-bonding between solute and solvent is somewhat underestimated [261,319-321]. In MD simulations the effect of the ethanol $(\mathrm{EtOH})$ as a co-solvent in different concentrations $(1,0.5$ and $0.1 \mathrm{M}$ ) have been investigated. EtOH is considered as a model to explore the balance of hydrophobic interactions and $\mathrm{H}$-bonds in the biological systems [322]. DFT calculation showed that the negative values of the $E_{a d s}$ and solvation energies $\left(E_{\text {sol }}\right)$, the difference between the energy obtained in solution and the energy obtained in gas, demonstrate that all studied configurations are stable. On going from the gas phase to water, an increase of the polarity of the considered configurations were observed, this is a desired property for drug delivery systems in the human body. Moreover, natural bond orbital (NBO) analysis showed that adsorption involves a charge transfer from the SW-CNT to FLU MD simulations indicated that the presence of $0.5 \mathrm{M}$ of ethanol solution increased the stability of the simulation system.

In the second work [315], the interaction between FLU and functionalized SW-CNT with carboxylic acid group ware investigated, again, by DFT calculations and MD simulations.

DFT calculations reveals that FLU is physisorbed on the surface. The formation of $\mathrm{H}$-bond between FLU and COOH group of functionalized SW-CNT had an important role in the stabilization of the adduct. MD simulations were useful for to examine the effect of SW-CNT chirality on the adsorption process. The results indicated that FLU on the SW-CNT with presented a $(10,5)$ chirality as reflected by the most negative $\mathrm{E}_{\mathrm{ads}}$ and a high number of $\mathrm{H}$-bonds between the functionals group of SW-CNT and drug molecules.

Hydroxyurea (HUR) (Figure 14) is another anticancer drug used in the treatment of several types of tumors [323]. The interaction between this drugs and carboxyl-functionalized SW-CNT were investigated using DFT calculations [324]. DFT calculations indicated that the complex formation is energetically favorable and it is exothermic as demonstrated by the enthalpy energy values. In addition, the H-bonding between - $\mathrm{COOH}$ and HUR play an important role for the different kinds of adsorption observed.

The interaction between new anticancer drug alectinib (ACB) (Figure 14) and SW-CNT have been studied using DFT calculations [325]. The results reveal that the adsorption of ACB over the SW-CNT change the calculated UV-vis spectra, in particular, the value $\lambda_{\max }$ was shifted from 261 to $452 \mathrm{~nm}$ and it is a bathochromic shift. Similar results have been obtained from calculated NMR spectra. Finally, the adsorption is governed by non-bonded interaction. 
The interaction between SW-CNT or their functionalization (with valine or phenylalanine moieties) and three anticancer drugs sorafenib (SRF), streptozotocin (STR) and sunitinib (SNB) (Figure 15) have been investigated by MD simulations [326]. SRF and SNB are a dual-action inhibitor that targets the RAF (rapidly accelerated fibrosarcoma)/MEK (mitogen-activated protein kinase kinase)/ extracellular signal-regulated kinase (ERK) pathway in tumor cells and tyrosine kinases VEGFR (vascular endothelial growth factor receptor)/PDGFR (platelet-derived growth factor receptors) in tumor vasculature. Although the mechanism was not fully elucidated and may vary between cell lines, a commonly observed theme is the inhibition of phosphorylation of the initiation factor eIF4E and loss of the antiapoptotic protein myeloid cell leukemia-1 (MCL-1) [327-329].

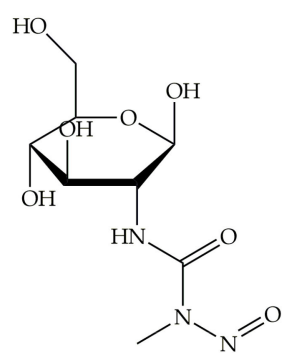

Streptozotocin (STR)

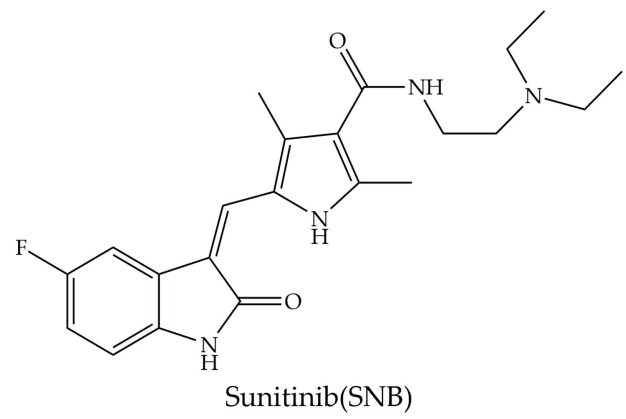

Sunitinib(SNB)<smiles>CNC(=O)c1cc(Oc2ccc(NC(=O)Nc3ccc(Cl)c(C(F)(F)F)c3)cc2)ccn1</smiles>

Sorafenib (SRF)

Figure 15. Streptozotocin, sunitinib and sorafinb anticancer agents.

STR is an alkylating agent [330], the alkylating activity is related to its nitrosourea moiety. Moreover STZ is a nitric oxide (NO) donor and is liberated when STR is metabolized inside cells, $\mathrm{NO}$-synthase protein is not required; this molecule contributes to STR induced DNA damage. However, there is so evidence that NO is not the only molecule responsible for the cytotoxic effect, indeed STR generate reactive oxygen species, which also contribute to DNA damage [331].

MD results showed that the type and the position of functional group influenced the van der Waals interaction energy between drugs and SW-CNT and the adsorption of drug molecules on its surface [326]. These three drugs interact with SW-CNT by $\pi-\pi$ stacking and H-bonding, however for STR the $\pi-\pi$ stacking are less strong. Results suggest that altering the functionalization of the nano-tube surface can affect the drug-nano-tube interaction [326].

\section{Conclusions and Outlook}

The interaction of pharmaceutical drugs with carbon nanomaterials has been studied in the last two decades in a high number of experimental and computational works. As far as the latter approach is concerned, quantum mechanical methods and classical MD simulations have been demonstrated to be able to provide data on drug-CNM interactions at different scales.

In general, drug-CNM interactions are non-covalent and especially van der Waals forces acting between the aromatic surface and the adsorbed drug are driving the process with non-modified CNM. This should be considered when choosing the type of functional in DFT calculations, by preferring dispersion-corrected ones. The effect of $\mathrm{pH}$ needs to be also taken into account when running calculations for two main reasons: $(i)$ the drug indeed can be distributed among differently protonated 
species which, in principle, have different adsorption properties; (ii) the presence of ionizable groups alters the surface charge. Free energy calculations suggest that desolvation upon adsorption/desorption is important, and thus the associated entropic contribution, as also observed from several available experimental and theoretical thermodynamic data (negative $\Delta \mathrm{G}_{\mathrm{ads}}$ and positive $\Delta \mathrm{H}_{\mathrm{ads}}$ ).

Finally, a good agreement between experimental and theoretical data has been observed, for: (i) values of $\mathrm{E}_{\mathrm{ads}}$ in most of the cases; (ii) values of $\Delta \mathrm{G}_{\mathrm{ads}}$; (iii) trends in IR, Raman, UV-vis and NMR spectra; $i v$ ) sorption and desorption time; $(v)$ type of interaction ( $\pi-\pi$ stacking, H-bond, electrostatic) involved in the adsorption process; (vi) the adsorption isotherm and kinetic model used to fit the data; (vii) influence of $\mathrm{pH}$ and solvent in the adsorption process. However, some discrepancies between experimental and theoretical data are found, in particular they seem to be due to the application of ideal models used in the experimental works, which do not take into account defects in the surface of the CNMs or the presence of supramolecular structures.

Therefore, computational studies provide a useful tool for investigating such systems and obtain molecular level details of the observed phenomena, and ultimately provide indications to guide $\mathrm{CNM}$-bases nano-carriers development design. As far as MD simulations are concerned, the availability of more powerful high performance computing platformsallows to treat increasingly complex systems along with longer simulation times.

Author Contributions: Writing—original draft preparation, D.V.; writing—review and editing, M.T. \& A.M.; supervision, A.M. All authors have read and agreed to the published version of the manuscript.

Funding: This research received no external funding.

Acknowledgments: This review has been developed in the framework of the European Community's H2020 Programme H2020-MSCA-RISE 2017 under the project RECOPHARMA (grant agreement \#778266).

Conflicts of Interest: Authors declare have no conflicts of interest.

\section{References}

1. Kroto, H.W.; Heath, J.R.; O’Brien, S.C.; Curl, R.F.; Smalley, R.E. C 60 : Buckminsterfullerene. Nature 1985, 318, 162-163. [CrossRef]

2. Iijima, S. Helical microtubules of graphitic carbon. Nature 1991, 354, 56-58. [CrossRef]

3. Bacon, R. Growth, structure, and properties of graphite whiskers. J. Appl. Phys. 1960, 31, 283-290. [CrossRef]

4. Novoselov, K.S.; Geim, A.K.; Morozov, S.V.; Jiang, D.; Zhang, Y.; Dubonos, S.V.; Grigorieva, I.V.; Firsov, A.A. Electric Field Effect in Atomically Thin Carbon Films. Science 2004, 306, 666-669. [CrossRef]

5. Mohan, V.B.; Lau, K.T.; Hui, D.; Bhattacharyya, D. Graphene-based materials and their composites: A review on production, applications and product limitations. Compos. Part B Eng. 2018, 142, 200-220. [CrossRef]

6. Lawal, A.T. Graphene-based nano composites and their applications. A review. Biosens. Bioelectron. 2019, 141, 111384. [CrossRef] [PubMed]

7. Apul, O.G.; Karanfil, T. Adsorption of synthetic organic contaminants by carbon nanotubes: A critical review. Water Res. 2014, 68, 34-55. [CrossRef]

8. Loh, K.P.; Bao, Q.; Ang, P.K.; Yang, J. The chemistry of graphene. J. Mater. Chem. 2010, 20, $2277-2289$. [CrossRef]

9. Zhang, W.; Zhang, Z.; Zhang, Y. The application of carbon nanotubes in target drug delivery systems for cancer therapies. Nanoscale Res. Lett. 2011, 6, 555. [CrossRef]

10. Ebbesen, T.W.; Lezec, H.J.; Hiura, H.; Bennett, J.W.; Ghaemi, H.F.; Thio, T. Electrical conductivity of individual carbon nanotubes. Nature 1996, 382, 54-56. [CrossRef]

11. White, C.T.; Todorov, T.N. Carbon nanotubes as long ballistic conductors. Nature 1998, 393, $240-241$. [CrossRef]

12. Wei, B.Q.; Vajtai, R.; Ajayan, P.M. Reliability and current carrying capacity of carbon nanotubes. Appl. Phys. Lett. 2001, 79, 1172-1174. [CrossRef]

13. Hills, G.; Lau, C.; Wright, A.; Fuller, S.; Bishop, M.D.; Srimani, T.; Kanhaiya, P.; Ho, R.; Amer, A.; Stein, Y.; et al. Modern microprocessor built from complementary carbon nanotube transistors. Nature 2019, 572, 595-602. [CrossRef] [PubMed] 
14. Treacy, M.M.J.; Ebbesen, T.W.; Gibson, J.M. Exceptionally high Young's modulus observed for individual carbon nanotubes. Nature 1996, 381, 678-680. [CrossRef]

15. Lu, J.P. Elastic properties of carbon nanotubes and nanoropes. Phys. Rev. Lett. 1997, 79, 1297-1300. [CrossRef]

16. Wong, E.W.; Sheehan, P.E.; Lieber, C.M. Nanobeam mechanics: Elasticity, strength, and toughness of nanorods and nanotubes. Science 1997, 277, 1971-1975. [CrossRef]

17. Schwamb, T.; Burg, B.R.; Schirmer, N.C.; Poulikakos, D. An electrical method for the measurement of the thermal and electrical conductivity of reduced graphene oxide nanostructures. Nanotechnology 2009, 20, 405704. [CrossRef]

18. De Volder, M.F.L.; Tawfick, S.H.; Baughman, R.H.; Hart, A.J. Carbon Nanotubes: Present and Future Commercial Applications. Science 2013, 339, 535-539. [CrossRef]

19. Krätschmer, W.; Lamb, L.D.; Fostiropoulos, K.; Huffman, D.R. Solid C60: A new form of carbon. Nature 1990, 347, 354-358. [CrossRef]

20. Thakral, S.; Mehta, R.M. Fullerenes: An introduction and overview of their biological properties. Indian J. Pharm. Sci. 2006, 68, 13-19. [CrossRef]

21. Geckeler, K.E.; Samal, S. Syntheses and properties of macromolecular fullerenes, a review. Polym. Int. 1999, 48, 743-757. [CrossRef]

22. Goodarzi, S.; Da Ros, T.; Conde, J.; Sefat, F.; Mozafari, M. Fullerene: Biomedical engineers get to revisit an old friend. Mater. Today 2017, 20,460-480. [CrossRef]

23. Acquah, S.F.A.; Penkov, A.V.; Markelov, D.A.; Semisalova, A.S.; Leonhardt, B.E.; Magi, J.M. Review-The beautiful molecule: 30 years of $\mathrm{C}_{60}$ and its derivatives. ECS J. Solid State Sci. Technol. 2017, 6, M3155-M3162. [CrossRef]

24. Castro, E.; Garcia, A.H.; Zavala, G.; Echegoyen, L. Fullerenes in biology and medicine. J. Mater. Chem. B 2017, 5, 6523-6535. [CrossRef] [PubMed]

25. Dresselhaus, M.S.; Dresselhaus, G.; Charlier, J.C.; Hernández, E. Electronic, thermal and mechanical properties of carbon nanotubes. Philos. Trans. Math. Phys. Eng. Sci. 2004, 362, 2065-2098. [CrossRef]

26. Hou, P.X.; Bai, S.; Yang, Q.H.; Liu, C.; Cheng, H.M. Multi-step purification of carbon nanotubes. Carbon 2002, 40, 81-85. [CrossRef]

27. Hirlekar, R.; Yamagar, M.; Garse, H.; Vij, M.; Kadam, V. Carbon Nanotubes and Its Applications: a Review. Asian J. Pharm. Clin. Res. 2009, 2, 17-27.

28. Chico, L.; Crespi, V.; Benedict, L.; Louie, S.; Cohen, M. Pure Carbon Nanoscale Devices: Nanotube Heterojunctions. Phys. Rev. Lett. 1996, 76, 971-974. [CrossRef]

29. Tessonnier, J.P.; Su, D.S. Recent progress on the growth mechanism of carbon nanotubes: A review. ChemSusChem 2011, 4, 824-847. [CrossRef]

30. Thostenson, E.T.; Ren, Z.; Chou, T.-W. Advances in the science and technology of carbon nanotubes and their composites: A review. Compos. Sci. Technol. 2001, 61, 1899-1912. [CrossRef]

31. Abbasi, E.; Aval, S.F.; Akbarzadeh, A.; Milani, M.; Nasrabadi, H.T.; Woo joo, S.; Hanifehpour, Y.; Nejati-Koshki, K.; Pashaei-Asl, R. Dendrimers: Synthesis, applications, and properties. Nanoscale Res. Lett. 2014, 9, 247. [CrossRef]

32. Gao, C.; Guo, Z.; Liu, J.H.; Huang, X.J. The new age of carbon nanotubes: An updated review of functionalized carbon nanotubes in electrochemical sensors. Nanoscale 2012, 4, 1948-1963. [CrossRef]

33. Negri, V.; Pacheco-Torres, J.; Calle, D.; López-Larrubia, P. Carbon Nanotubes in Biomedicine. Top. Curr. Chem. 2020, 378, 15. [CrossRef] [PubMed]

34. Kuila, T.; Bose, S.; Mishra, A.K.; Khanra, P.; Kim, N.H.; Lee, J.H. Chemical functionalization of graphene and its applications. Prog. Mater. Sci. 2012, 57, 1061-1105. [CrossRef]

35. Craciun, M.F.; Khrapach, I.; Barnes, M.D.; Russo, S. Properties and applications of chemically functionalized graphene. J. Phys. Condens. Matter 2013, 25, 423201. [CrossRef] [PubMed]

36. Sprinkle, M.; Ruan, M.; Hu, Y.; Hankinson, J.; Rubio-Roy, M.; Zhang, B.; Wu, X.; Berger, C.; de Heer, W.A. Scalable templated growth of graphene nanoribbons on SiC. Nat. Nanotechnol. 2010, 5, 727-731. [CrossRef] [PubMed]

37. Avouris, P.; Dimitrakopoulos, C. Graphene: Synthesis and applications. Mater. Today 2012, 15, 86-97. [CrossRef] 
38. Park, S.; An, J.; Jung, I.; Piner, R.D.; An, S.J.; Li, X.; Velamakanni, A.; Ruoff, R.S. Colloidal Suspensions of Highly Reduced Graphene Oxide in a Wide Variety of Organic Solvents. Nano Lett. 2009, 9, 1593-1597. [CrossRef]

39. Kim, J.; Cote, L.J.; Kim, F.; Yuan, W.; Shull, K.R.; Huang, J. Graphene Oxide Sheets at Interfaces. J. Am. Chem. Soc. 2010, 132, 8180-8186. [CrossRef]

40. Kim, F.; Cote, L.J.; Huang, J. Graphene Oxide: Surface Activity and Two-Dimensional Assembly. Adv. Mater. 2010, 22, 1954-1958. [CrossRef]

41. Guo, F.; Kim, F.; Han, T.H.; Shenoy, V.B.; Huang, J.; Hurt, R.H. Hydration-Responsive Folding and Unfolding in Graphene Oxide Liquid Crystal Phases. ACS Nano 2011, 23, 8019-8025. [CrossRef] [PubMed]

42. Bagri, A.; Mattevi, C.; Acik, M.; Chabal, Y.J.; Chhowalla, M.; Shenoy, V.B. Structural evolution during the reduction of chemically derived graphene oxide. Nat. Chem. 2010, 2, 581-587. [CrossRef]

43. Smalley, R.E.; Yakobson, B.I. The future of the fullerenes. Solid State Commun. 1998, 107, 597-606. [CrossRef]

44. Ruhl, G.; Wittmann, S.; Koenig, M.; Neumaier, D. The integration of graphene into microelectronic devices. Beilstein J. Nanotechnol. 2017, 8, 1056-1064. [CrossRef]

45. Wang, X.; Liu, Y.; Xu, J.; Li, S.; Zhang, F.; Ye, Q.; Zhai, X.; Zhao, X. Molecular dynamics study of binding strength and drug diffusion of graphene-based drug delivery systems. J. Funct. Mater. 2015, 46, 16052-16058.

46. Li, X.; Zhi, L. Graphene hybridization for energy storage applications. Chem. Soc. Rev. 2018, 47, 3189-3216. [CrossRef] [PubMed]

47. Kharissova, O.V.; Kharisov, B.I.; Oliva González, C.M. Carbon-Carbon Allotropic Hybrids and Composites: Synthesis, Properties, and Applications. Ind. Eng. Chem. Res. 2019, 58, 3921-3948. [CrossRef]

48. Raphey, V.R.; Henna, T.K.; Nivitha, K.P.; Mufeedha, P.; Sabu, C.; Pramod, K. Advanced biomedical applications of carbon nanotube. Mater. Sci. Eng. C 2019, 100, 616-630. [CrossRef] [PubMed]

49. Dasari Shareena, T.P.; McShan, D.; Dasmahapatra, A.K.; Tchounwou, P.B. A Review on Graphene-Based Nanomaterials in Biomedical Applications and Risks in Environment and Health. Nano-Micro Lett. 2018, 10, 53. [CrossRef]

50. Ahadian, S.; Davenport Huyer, L.; Estili, M.; Yee, B.; Smith, N.; Xu, Z.; Sun, Y.; Radisic, M. Moldable elastomeric polyester-carbon nanotube scaffolds for cardiac tissue engineering. Acta Biomater. 2017, 52, 81-91. [CrossRef]

51. Gajendiran, M.; Choi, J.; Kim, S.J.; Kim, K.; Shin, H.; Koo, H.J.; Kim, K. Conductive biomaterials for tissue engineering applications. J. Ind. Eng. Chem. 2017, 51, 12-26. [CrossRef]

52. Nongbe, M.C.; Ekou, T.; Ekou, L.; Yao, K.B.; Le Grognec, E.; Felpin, F.X. Biodiesel production from palm oil using sulfonated graphene catalyst. Renew. Energy 2017, 106, 135-141. [CrossRef]

53. López-Andarias, J.; Frontera, A.; Matile, S. Anion-p Catalysis on Fullerenes. J. Am. Chem. Soc. 2017, 139, 13296-13299. [CrossRef] [PubMed]

54. Esteves, L.M.; Oliveira, H.A.; Passos, F.B. Carbon nanotubes as catalyst support in chemical vapor deposition reaction: A review. J. Ind. Eng. Chem. 2018, 65, 1-12. [CrossRef]

55. Li, Y.; Sun, B. Nano-delivery materials: Review of development and application in drug/gene transport. Key Eng. Mater. 2019, 803, 158-166. [CrossRef]

56. Demetzos, C.; Pippa, N. Advanced drug delivery nanosystems (aDDnSs): A mini-review. Drug Deliv. 2014, 21, 250-257. [CrossRef] [PubMed]

57. Li, J.; Yap, S.Q.; Yoong, S.L.; Nayak, T.R.; Chandra, G.W.; Ang, W.H.; Panczyk, T.; Ramaprabhu, S.; Vashist, S.K.; Sheu, F.S.; et al. Carbon nanotube bottles for incorporation, release and enhanced cytotoxic effect of cisplatin. Carbon 2012, 50, 1625-1634. [CrossRef]

58. Natarajan, J.V.; Nugraha, C.; Ng, X.W.; Venkatraman, S. Sustained-release from nanocarriers: A review. J. Control. Release 2014, 193, 122-138. [CrossRef]

59. Arora, D.; Jaglan, S. Nanocarriers based delivery of nutraceuticals for cancer prevention and treatment: A review of recent research developments. Trends Food Sci. Technol. 2016, 54, 114-126. [CrossRef]

60. Mehra, N.K.; Palakurthi, S. Interactions between carbon nanotubes and bioactives: A drug delivery perspective. Drug Discov. Today 2016, 21, 585-597. [CrossRef]

61. Yu, X.; Cheng, H.; Zhang, M.; Zhao, Y.; Qu, L.; Shi, G. Graphene-based smart materials. Nat. Rev. Mater. 2017, 2, 17046. [CrossRef]

62. Yang, K.; Feng, L.; Liu, Z. Stimuli responsive drug delivery systems based on nano-graphene for cancer therapy. Adv. Drug Deliv. Rev. 2016, 105, 228-241. [CrossRef] [PubMed] 
63. Kazemzadeh, H.; Mozafari, M. Fullerene-based delivery systems. Drug Discov. Today 2019, 24, 898-905. [CrossRef] [PubMed]

64. Datsyuk, V.; Kalyva, M.; Papagelis, K.; Parthenios, J.; Tasis, D.; Siokou, A.; Kallitsis, I.; Galiotis, C. Chemical oxidation of multiwalled carbon nanotubes. Carbon 2008, 46, 833-840. [CrossRef]

65. Peng, W.; Li, H.; Liu, Y.; Song, S. A review on heavy metal ions adsorption from water by graphene oxide and its composites. J. Mol. Liq. 2017, 230, 496-504. [CrossRef]

66. Wang, B.; Wang, J.; Zhu, J. Fluorination of graphene: A Spectroscopic and microscopic study. ACS Nano 2014, 8, 1862-1870. [CrossRef]

67. Kabdulov, M.; Jansen, M.; Amsharov, K.Y. Bottom-up $\mathrm{C}_{60}$ fullerene construction from a fluorinated $\mathrm{C} 60 \mathrm{H}_{21} \mathrm{~F}_{9}$ precursor by laser-induced tandem cyclization. Chem. A Eur. J. 2013, 19, 17262-17266. [CrossRef]

68. Adamska, M.; Narkiewicz, U. Fluorination of Carbon Nanotubes - A Review. J. Fluor. Chem. 2017, 200, 179-189. [CrossRef]

69. Wang, S.; Li, S.; Hou, C.; Ma, G.; Wang, H.; Wu, J.; Hao, X.; Zhang, H. Functionalization of multiwalled carbon nanotubes by amidation and Michael addition reactions and the effect of the functional chains on the properties of waterborne polyurethane composites. J. Appl. Polym. Sci. 2018, 135, 46757. [CrossRef]

70. Bjelaković, M.S.; Kop, T.J.; Vlajić, M.; DorCevie, J.; Milić, D.R. Design, synthesis, and characterization of fullerene-peptide-steroid covalent hybrids. Tetrahedron 2014, 70, 8564-8570. [CrossRef]

71. Zheng, L.; Zhen, W. Preparation and characterization of amidated graphene oxide and its effect on the performance of poly(lactic acid). Iran. Polym. J. 2018, 27, 239-252. [CrossRef]

72. Hsu, M.H.; Chuang, H.; Cheng, F.Y.; Huang, Y.P.; Han, C.C.; Pao, K.C.; Chou, S.C.; Shieh, F.K.; Tsai, F.Y.; Lin, C.C.; et al. Simple and highly efficient direct thiolation of the surface of carbon nanotubes. RSC Adv. 2014, 4, 14777-14780. [CrossRef]

73. Frare, M.C.; Pilot, R.; De Filippo, C.C.; Weber, V.; Signorini, R.; Maggini, M.; Bozio, R. Fullerene functionalized gold nanoparticles for optical limiting of continuous wave lasers. Appl. Phys. B Lasers Opt. 2019, 125, 47. [CrossRef]

74. Pereira De Sousa, I.; Buttenhauser, K.; Suchaoin, W.; Partenhauser, A.; Perrone, M.; Matuszczak, B.; Bernkop-Schnürch, A. Thiolated graphene oxide as promising mucoadhesive carrier for hydrophobic drugs. Int. J. Pharm. 2016, 509, 360-367. [CrossRef] [PubMed]

75. Jia, Z.; Wang, Y. Covalently crosslinked graphene oxide membranes by esterification reactions for ions separation. J. Mater. Chem. A 2015, 3, 4405-4412. [CrossRef]

76. Wang, Z.; Sun, L.; Li, X.; Li, B.; Wang, S. Preparation and Characterization of Thermal Conductive Composite Membranes of Aligned Esterified Carbon Nanotubes/Poly(vinylidene fluoride). Polym. Plast. Technol. Eng. 2015, 54, 515-522. [CrossRef]

77. Wang, H.; Gu, W.; Xiao, N.; Ye, L.; Xu, Q. Chlorotoxin-conjugated graphene oxide for targeted delivery of an anticancer drug. Int. J. Nanomedicine 2014, 9, 1433-1442.

78. Rana, V.K.; Choi, M.C.; Kong, J.Y.; Kim, G.Y.; Kim, M.J.; Kim, S.H.; Mishra, S.; Singh, R.P.; Ha, C.S. Synthesis and drug-delivery behavior of chitosan-functionalized graphene oxide hybrid nanosheets. Macromol. Mater. Eng. 2011, 296, 131-140. [CrossRef]

79. Kavitha, T.; Haider Abdi, S.I.; Park, S.Y. pH-sensitive nanocargo based on smart polymer functionalized graphene oxide for site-specific drug delivery. PPhys. Chem. Chem. Phys. 2013, 15, 5176-5185. [CrossRef]

80. Xu, H.; Fan, M.; Elhissi, A.M.A.; Zhang, Z.; Wan, K.W.; Ahmed, W.; Phoenix, D.A.; Sun, X. PEGylated graphene oxide for tumor-targeted delivery of paclitaxel. Nanomedicine 2015, 10, 1247-1262. [CrossRef]

81. Kam, N.W.S.; Dai, H. Single walled carbon nanotubes for transport and delivery of biological cargos. Phys. Status Solidi Basic Res. 2006, 243, 3561-3566.

82. Cho, Y.; Choi, Y. Graphene oxide-photosensitizer conjugate as a redox-responsive theranostic agent. Chem. Commun. 2012, 48, 9912-9914. [CrossRef] [PubMed]

83. Chen, R.; Zhao, T.; Wu, W.; Wu, F.; Li, L.; Qian, J.; Xu, R.; Wu, H.; Albishri, H.M.; Al-Bogami, A.S.; et al. Free-standing hierarchically sandwich-type tungsten disulfide nanotubes/graphene anode for lithium-ion batteries. Nano Lett. 2014, 14, 5899-5904. [CrossRef]

84. Wu, C.S.; Liao, H.T. Study on the preparation and characterization of biodegradable polylactide/multi-walled carbon nanotubes nanocomposites. Polymer (Guildf) 2007, 48, 4449-4458. [CrossRef] 
85. Meng, N.; Su, Y.T.; Zhou, N.; Zhang, M.; Shao, M.; Fan, Y.; Zhu, H.; Yuan, P.; Chi, C.; Xiao, Y. Carboxylated graphene oxide functionalized with $\beta$-cyclodextrin-Engineering of a novel nanohybrid drug carrier. Int. J. Biol. Macromol. 2016, 93, 117-122. [CrossRef]

86. Kumar, M.; Chung, J.S.; Kong, B.S.; Kim, E.J.; Hur, S.H. Synthesis of graphene-polyurethane nanocomposite using highly functionalized graphene oxide as pseudo-crosslinker. Mater. Lett. 2013, 106, 319-321. [CrossRef]

87. Gan, S.; Zakaria, S.; Chia, C.H.; Chen, R.S.; Jeyalaldeen, N. Physico-mechanical properties of a microwave-irradiated kenaf carbamate/graphene oxide membrane. Cellulose 2015, 22, 3851-3863. [CrossRef]

88. Tao, C.A.; Wang, J.; Qin, S.; Lv, Y.; Long, Y.; Zhu, H.; Jiang, Z. Fabrication of pH-sensitive graphene oxide-drug supramolecular hydrogels as controlled release systems. J. Mater. Chem. 2012, 22, 24856-24861. [CrossRef]

89. Shi, J.; Liu, Y.; Wang, L.; Gao, J.; Zhang, J.; Yu, X.; Ma, R.; Liu, R.; Zhang, Z. A tumoral acidic pH-responsive drug delivery system based on a novel photosensitizer (fullerene) for in vitro and in vivo chemo-photodynamic therapy. Acta Biomater. 2014, 10, 1280-1291. [CrossRef]

90. Qiu, J.; Zhang, R.; Li, J.; Sang, Y.; Tang, W.; Gil, P.R.; Liu, H. Fluorescent graphene quantum dots as traceable, pH-sensitive drug delivery systems. Int. J. Nanomedicine 2015, 10, 6709-6724.

91. Qin, Y.; Chen, J.; Bi, Y.; Xu, X.; Zhou, H.; Gao, J.; Hu, Y.; Zhao, Y.; Chai, Z. Near-infrared light remote-controlled intracellular anti-cancer drug delivery using thermo/pH sensitive nanovehicle. Acta Biomater. 2015, 17, 201-209. [CrossRef] [PubMed]

92. Mo, Y.; Wang, H.; Liu, J.; Lan, Y.; Guo, R.; Zhang, Y.; Xue, W.; Zhang, Y. Controlled release and targeted delivery to cancer cells of doxorubicin from polysaccharide-functionalised single-walled carbon nanotubes. J. Mater. Chem. B 2015, 3, 1846-1855. [CrossRef] [PubMed]

93. Liu, J.; Cui, L.; Kong, N.; Barrow, C.J.; Yang, W. RAFT controlled synthesis of graphene/polymer hydrogel with enhanced mechanical property for $\mathrm{pH}$-controlled drug release. Eur. Polym. J. 2014, 50, 9-17. [CrossRef]

94. Liang, S.; Zhao, Y.; Adronov, A. Selective and reversible noncovalent functionalization of single-walled carbon nanotubes by a $\mathrm{pH}$-responsive vinylogous tetrathiafulvalene-fluorene copolymer. J. Am. Chem. Soc. 2014, 136, 970-977. [CrossRef] [PubMed]

95. Kim, S.; Lee, D.J.; Kwag, D.S.; Lee, U.Y.; Youn, Y.S.; Lee, E.S. Acid pH-activated glycol chitosan/fullerene nanogels for efficient tumor therapy. Carbohydr. Polym. 2014, 101, 692-698. [CrossRef]

96. Depan, D.; Shah, J.; Misra, R.D.K. Controlled release of drug from folate-decorated and graphene mediated drug delivery system: Synthesis, loading efficiency, and drug release response. Mater. Sci. Eng. C 2011, 31, 1305-1312. [CrossRef]

97. Ardeshirzadeh, B.; Anaraki, N.A.; Irani, M.; Rad, L.R.; Shamshiri, S. Controlled release of doxorubicin from electrospun PEO/chitosan/graphene oxide nanocomposite nanofibrous scaffolds. Mater. Sci. Eng. C 2015, 48, 384-390. [CrossRef]

98. Yoon, H.J.; Shanker, A.; Wang, Y.; Kozminsky, M.; Jin, Q.; Palanisamy, N.; Burness, M.L.; Azizi, E.; Simeone, D.M.; Wicha, M.S.; et al. Tunable Thermal-Sensitive Polymer-Graphene Oxide Composite for Efficient Capture and Release of Viable Circulating Tumor Cells. Adv. Mater. 2016, 28, 4891-4897. [CrossRef]

99. Teodorescu, F.; Oz, Y.; Quéniat, G.; Abderrahmani, A.; Foulon, C.; Lecoeur, M.; Sanyal, R.; Sanyal, A.; Boukherroub, R.; Szunerits, S. Photothermally triggered on-demand insulin release from reduced graphene oxide modified hydrogels. J. Control. Release 2017, 246, 164-173. [CrossRef]

100. Pistone, A.; Iannazzo, D.; Ansari, S.; Milone, C.; Salamò, M.; Galvagno, S.; Cirmi, S.; Navarra, M. Tunable doxorubicin release from polymer-gated multiwalled carbon nanotubes. Int. J. Pharm. 2016, 515, 30-36. [CrossRef]

101. Hashemi, M.; Yadegari, A.; Yazdanpanah, G.; Omidi, M.; Jabbehdari, S.; Haghiralsadat, F.; Yazdian, F.; Tayebi, L. Normalization of doxorubicin release from graphene oxide: New approach for optimization of effective parameters on drug loading. Biotechnol. Appl. Biochem. 2017, 64, 433-442. [CrossRef] [PubMed]

102. Yu, F.; Li, Y.; Han, S.; Ma, J. Adsorptive removal of antibiotics from aqueous solution using carbon materials. Chemosphere 2016, 153, 365-385. [CrossRef] [PubMed]

103. Gehrke, I.; Geiser, A.; Somborn-schulz, A. Innovations in nanotechnology for water treatment. Nanotechnol. Sci. Appl. 2015, 8, 1-17. [CrossRef] [PubMed]

104. Rivera-utrilla, J.; Sánchez-polo, M.; Ferro-garcía, M.Á.; Prados-joya, G.; Ocampo-Perez, R. Pharmaceuticals as emerging contaminants and their removal from water. A review. Chemosphere 2013, 9, 1268-1287. [CrossRef] [PubMed] 
105. Gothwal, R.; Shashidhar, T. Antibiotic Pollution in the Environment: A Review. Clean - Soil, wat 2015, 43, 479-489. [CrossRef]

106. Tiwari, B.; Sellamuthu, B.; Ouarda, Y.; Drogui, P.; Tyagi, R.D.; Buelna, G. Review on fate and mechanism of removal of pharmaceutical pollutants from wastewater using biological approach. Bioresour. Technol. 2017, 224, 1-12. [CrossRef]

107. Quesada, H.B.; Baptista, A.T.A.; Cusioli, L.F.; Seibert, D.; de Oliveira Bezerra, C.; Bergamasco, R. Surface water pollution by pharmaceuticals and an alternative of removal by low-cost adsorbents: A review. Chemosphere 2019, 222, 766-780. [CrossRef]

108. Santhosh, C.; Velmurugan, V.; Jacob, G.; Jeong, S.K.; Grace, A.N.; Bhatnagar, A. Role of nanomaterials in water treatment applications: A review. Chem. Eng. J. 2016, 306, 1116-1137. [CrossRef]

109. Patel, M.; Kumar, R.; Kishor, K.; Mlsna, T.; Pittman, C.U.; Mohan, D. Pharmaceuticals of Emerging Concern in Aquatic Systems: Chemistry, Occurrence, Effects, and Removal Methods. Chem. Rev. 2019, 119, 3510-3673. [CrossRef]

110. Kanakaraju, D.; Glass, B.D.; Oelgemöller, M. Advanced oxidation process-mediated removal of pharmaceuticals from water: A review. J. Environ. Manage. 2018, 219, 189-207. [CrossRef]

111. Miklos, D.B.; Remy, C.; Jekel, M.; Linden, K.G.; Drewes, J.E.; Hübner, U. Evaluation of advanced oxidation processes for water and wastewater treatment - A critical review. Water Res. 2018, 139, 118-131. [CrossRef] [PubMed]

112. Patel, N.; Khan, M.Z.A.; Shahane, S.; Rai, D.; Chauhan, D.; Kant, C.; Chaudhary, V.K. Emerging Pollutants in Aquatic Environment: Source, Effect, and Challenges in Biomonitoring and Bioremediation- A Review. Pollution 2020, 6, 99-113.

113. Vieno, N.; Tuhkanen, T.; Kronberg, L. Removal of pharmaceuticals in drinking water treatment: Effect of chemical coagulation. Environ. Technol. 2006, 27, 183-192. [CrossRef] [PubMed]

114. Alexander, J.T.; Hai, F.I.; Al-aboud, T.M. Chemical coagulation-based processes for trace organic contaminant removal: Current state and future potential. J. Environ. Manage. 2012, 111, 195-207. [CrossRef]

115. Yu-Chen Lin, A.; Hsueh, J.H.-F.; Hong, P.K.A. Removal of antineoplastic drugs cyclophosphamide, ifosfamide, and 5-fluorouracil and a vasodilator drug pentoxifylline from wastewaters by ozonation. Environ. Sci. Pollut. Res. 2015, 22, 508-515.

116. Wei, C.; Zhang, F.; Hu, Y.; Feng, C.; Wu, H. Ozonation in water treatment: The generation, basic properties of ozone and its practical application. Rev. Chem. Eng. 2017, 33, 49-89. [CrossRef]

117. Ikehata, K.; Jodeiri Naghashkar, N.; Gamal El-Din, M. Degradation of aqueous pharmaceuticals by ozonation and advanced oxidation processes: A review. Ozone Sci. Eng. 2006, 28, 353-414. [CrossRef]

118. Rodriguez-Mozaz, S.; Ricart, M.; Köck-Schulmeyer, M.; Guasch, H.; Bonnineau, C.; Proia, L.; de Alda, M.L.; Sabater, S.; Barceló, D. Pharmaceuticals and pesticides in reclaimed water: Efficiency assessment of a microfiltration-reverse osmosis (MF-RO) pilot plant. J. Hazard. Mater. 2015, 282, 165-173. [CrossRef]

119. Joo, S.H.; Tansel, B. Novel technologies for reverse osmosis concentrate treatment: A review. J. Environ. Manage. 2015, 150, 322-335. [CrossRef]

120. Wang, X.; Yin, R.; Zeng, L.; Zhu, M. A review of graphene-based nanomaterials for removal of antibiotics from aqueous environments. Environ. Pollut. 2019, 253, 100-110. [CrossRef]

121. Khan, A.; Wang, J.; Li, J.; Wang, X.; Chen, Z.; Alsaedi, A.; Hayat, T.; Chen, Y.; Wang, X. The role of graphene oxide and graphene oxide-based nanomaterials in the removal of pharmaceuticals from aqueous media: A review. Environ. Sci. Pollut. Res. 2017, 24, 7938-7958. [CrossRef] [PubMed]

122. Carmalin Sophia, A.; Lima, E.C.; Allaudeen, N.; Rajan, S. Application of graphene based materials for adsorption of pharmaceutical traces from water and wastewater- a review. Desalin. Water Treat. 2016, 57, 27573-27586. [CrossRef]

123. Son, K.H.; Hong, J.H.; Lee, J.W. Carbon nanotubes as cancer therapeutic carriers and mediators. Int. J. Nanomed. 2016, 11, 5163-5185. [CrossRef] [PubMed]

124. Rastogi, V.; Yadav, P.; Bhattacharya, S.S.; Mishra, A.K.; Verma, N.; Verma, A.; Pandit, J.K. Carbon Nanotubes: An Emerging Drug Carrier for Targeting Cancer Cells. J. Drug Deliv. 2014, 2014, 670815. [CrossRef] [PubMed]

125. Li, J.; Pant, A.; Chin, C.F.; Ang, W.H.; Ménard-Moyon, C.; Nayak, T.R.; Gibson, D.; Ramaprabhu, S.; Panczyk, T.; Bianco, A.; et al. In vivo biodistribution of platinum-based drugs encapsulated into multi-walled carbon nanotubes. Nanomed. Nanotechnol. Biol. Med. 2014, 10, 1465-1475. [CrossRef] [PubMed] 
126. Shim, G.; Kim, M.G.; Park, J.Y.; Oh, Y.K. Graphene-based nanosheets for delivery of chemotherapeutics and biological drugs. Adv. Drug Deliv. Rev. 2016, 105, 205-227. [CrossRef]

127. Song, W.; Yang, T.; Wang, X.; Sun, Y.; Ai, Y.; Sheng, G.; Hayat, T.; Wang, X. Experimental and theoretical evidence for competitive interactions of tetracycline and sulfamethazine with reduced graphene oxides. Environ. Sci. Nano 2016, 3, 1318-1326. [CrossRef]

128. Wang, F.; Ma, S.; Si, Y.; Dong, L.; Wang, X.; Yao, J.; Chen, H.; Yi, Z.; Yao, W.; Xing, B. Interaction mechanisms of antibiotic sulfamethoxazole with various graphene-based materials and multiwall carbon nanotubes and the effect of humic acid in water. Carbon 2017, 114, 671-678. [CrossRef]

129. Zhao, L.; Dong, P.; Xie, J.; Li, J.; Wu, L.; Yang, S.-T.; Luo, J. Porous graphene oxide-chitosan aerogel for tetracycline removal. Mater. Res. Express 2013, 1, 15601. [CrossRef]

130. Tang, Y.; Guo, H.; Xiao, L.; Yu, S.; Gao, N.; Wang, Y. Synthesis of reduced graphene oxide/magnetite composites and investigation of their adsorption performance of fluoroquinolone antibiotics. Colloids Surfaces A Physicochem. Eng. Asp. 2013, 424, 74-80. [CrossRef]

131. Chen, H.; Gao, B.; Li, H. Removal of sulfamethoxazole and ciprofloxacin from aqueous solutions by graphene oxide. J. Hazard. Mater. 2015, 282, 201-207. [CrossRef] [PubMed]

132. Rostamian, R.; Behnejad, H. A unified platform for experimental and quantum mechanical study of antibiotic removal from water. J. Water Process Eng. 2017, 17, 207-215. [CrossRef]

133. Li, M.F.; Liu, Y.G.; Zeng, G.M.; Liu, N.; Liu, S.B. Graphene and graphene-based nanocomposites used for antibiotics removal in water treatment: A review. Chemosphere 2019, 226, 360-380. [CrossRef]

134. Ho, Y.S. Review of second-order models for adsorption systems. J. Hazard. Mater. 2006, 136, 681-689. [CrossRef]

135. Wang, F.; Yang, B.; Wang, H.; Song, Q.; Tan, F.; Cao, Y. Removal of ciprofloxacin from aqueous solution by a magnetic chitosan grafted graphene oxide composite. J. Mol. Liq. 2016, 222, 188-194. [CrossRef]

136. Rostamian, R.; Amiri, N.; Behnejad, H. How does graphene nanosheet affect the pharmaceutical adsorption? A comprehensive insight from molecular dynamics simulation, quantum mechanics and experimental study. J. Mol. Liq. 2018, 269, 29-37. [CrossRef]

137. Farahani, B.V.; Behbahani, G.R.; Javadi, N. Functionalized multi walled carbon nanotubes as a carrier for doxorubicin: Drug adsorption study and statistical optimization of drug loading by factorial design methodology. J. Braz. Chem. Soc. 2016, 27, 694-705. [CrossRef]

138. Sabna, V.; Thampi, S.G.; Chandrakaran, S. Adsorption of crystal violet onto functionalised multi-walled carbon nanotubes: Equilibrium and kinetic studies. Ecotoxicol. Environ. Saf. 2016, 134, 390-397. [CrossRef]

139. Jorgensen, W.L. The Many Roles of Computation in Drug Discovery. Science 2004, 303, 1813-1818. [CrossRef]

140. Sliwoski, G.; Kothiwale, S.; Meiler, J.; Lowe, E.W.J. Computational methods in drug discovery. Pharmacol. Rev. 2014, 66, 334-395. [CrossRef]

141. Ruiz, V.G.; Liu, W.; Tkatchenko, A. Density-functional theory with screened van der Waals interactions applied to atomic and molecular adsorbates on close-packed and non-close-packed surfaces. Phys. Rev. B 2016, 93, 35118. [CrossRef]

142. Tang, Q.; Zhou, Z.; Chen, Z. Innovation and discovery of graphene-like materials via density-functional theory computations. Wiley Interdiscip. Rev. Comput. Mol. Sci. 2015, 5, 360-379. [CrossRef]

143. Botu, V.; Ramprasad, R. Adaptive machine learning framework to accelerate ab initio molecular dynamics. Int. J. Quantum Chem. 2015, 115, 1074-1083. [CrossRef]

144. Cramer, C.J. Essentials of Computational Chemistry: Theories and Models; Wiley: Chichester, UK, 2004; ISBN 0470091827.

145. Frenkel, D.; Smit, B. Understanding Molecular Simulation: From Algorithms to Applications, 2nd ed.; Academic Press: Harcourt, FL, USA, 2002; ISBN 0122673514.

146. Huang, J.; MacKerell Jr, A.D. CHARMM36 all-atom additive protein force field: Validation based on comparison to NMR data. J. Comput. Chem. 2013, 34, 2135-2145. [CrossRef] [PubMed]

147. Lee, S.; Tran, A.; Allsopp, M.; Lim, J.B.; Hénin, J.; Klauda, J.B. CHARMM36 United Atom Chain Model for Lipids and Surfactants. J. Phys. Chem. B 2014, 118, 547-556. [CrossRef] [PubMed]

148. Dickson, C.J.; Madej, B.D.; Skjevik, Å.A.; Betz, R.M.; Teigen, K.; Gould, I.R.; Walker, R.C. Lipid14: The Amber Lipid Force Field. J. Chem. Theory Comput. 2014, 10, 865-879. [CrossRef] [PubMed] 
149. Cornell, W.D.; Cieplak, P.; Bayly, C.I.; Gould, I.R.; Merz, K.M.; Ferguson, D.M.; Spellmeyer, D.C.; Fox, T.; Caldwell, J.W.; Kollman, P.A. A Second Generation Force Field for the Simulation of Proteins, Nucleic Acids, and Organic Molecules. J. Am. Chem. Soc. 1995, 117, 5179-5197. [CrossRef]

150. Pechlaner, M.; Reif, M.M.; Oostenbrink, C. Reparametrisation of united-atom amine solvation in the GROMOS force field. Mol. Phys. 2017, 115, 1144-1154. [CrossRef]

151. Müller-Dethlefs, K.; Hobza, P. Noncovalent Interactions: A Challenge for Experiment and Theory. Chem. Rev. 2000, 100, 143-167. [CrossRef]

152. Pettersson, I.; Liljefors, T. Benzene-benzene (phenyl-phenyl) interactions in MM2/MMP2 molecular mechanics calculations. J. Comput. Chem. 1987, 8, 1139-1145. [CrossRef]

153. Hobza, P.; Selzle, H.L.; Schlag, E.W. Floppy structure of the benzene dimer: Ab initio calculation on the structure and dipole moment. J. Chem. Phys. 1990, 93, 5893-5897. [CrossRef]

154. Hentschke, R.; Winkler, R.G. Molecular dynamics simulation study of the adsorption of chain alkanes from solution onto graphite. J. Chem. Phys. 1993, 99, 5528-5534. [CrossRef]

155. Hobza, P.; Selzle, H.L.; Schlag, E.W. Potential Energy Surface of the Benzene Dimer: Ab Initio Theoretical Study. J. Am. Chem. Soc. 1994, 116, 3500-3506. [CrossRef]

156. Tsuzuki, S.; Uchimaru, T.; Mikami, M.; Tanabe, K. Basis set effects on the calculated bonding energies of neutral benzene dimers: Importance of diffuse polarization functions. Chem. Phys. Lett. 1996, 252, 206-210. [CrossRef]

157. Tsuzuki, S.; Honda, K.; Uchimaru, T.; Mikami, M. Ab initio calculations of structures and interaction energies of toluene dimers including $\operatorname{CCSD}(\mathrm{T})$ level electron correlation correction. J. Chem. Phys. 2005, 122, 144323. [CrossRef]

158. Zhao, Y.; Truhlar, D.G. Multicoefficient extrapolated density functional theory studies of $\pi \cdots \pi$ interactions: The benzene dimer. J. Phys. Chem. A 2005, 109, 4209-4212. [CrossRef]

159. Lee, E.C.; Kim, D.; Jurečka, P.; Tarakeshwar, P.; Hobza, P.; Kim, K.S. Understanding of assembly phenomena by aromatic-aromatic interactions: Benzene Dimer and the substituted systems. J. Phys. Chem. A 2007, 111, 3446-3457. [CrossRef]

160. Grimme, S.; Ehrlich, S.; Goerigk, L. Effect of the Damping Function in Dispersion Corrected Density Functional Theory. J. Comput. Chem. 2012, 32, 174-182. [CrossRef]

161. Schnell, M.; Erlekam, U.; Bunker, P.R.; Vonhelden, G.; Grabow, J.U.; Meijer, G.; Vanderavoird, A. Structure of the benzene dimer - Governed by dynamics. Angew. Chem. Int. Ed. 2013, 52, 5180-5183. [CrossRef]

162. Miliordos, E.; Aprà, E.; Xantheas, S.S. Benchmark theoretical study of the $\pi-\pi$ binding energy in the benzene dimer. J. Phys. Chem. A 2014, 118, 7568-7578. [CrossRef]

163. Zhan, Y.Z.; Zhao, X.; Wang, W. Theoretical study of the interaction energy of benzodifuranone dye molecule rings. Color. Technol. 2017, 133, 50-56. [CrossRef]

164. Sherrill, C.D.; Takatani, T.; Hohenstein, E.G. An assessment of theoretical methods for nonbonded interactions: Comparison to complete basis set limit coupled-cluster potential energy curves for the benzene dimer, the methane dimer, benzene-methane, and benzene- $\mathrm{H}_{2}$ S. J. Phys. Chem. A 2009, 113, 10146-10159. [CrossRef] [PubMed]

165. Ruuska, H.; Pakkanen, T.A. Ab initio study of interlayer interaction of graphite: Benzene-coronene and coronene dimer two-layer models. J. Phys. Chem. B 2001, 105, 9541-9547. [CrossRef]

166. Chakarova-Käck, S.D.; Schröder, E.; Lundqvist, B.I.; Langreth, D.C. Application of van der Waals density functional to an extended system: Adsorption of benzene and naphthalene on graphite. Phys. Rev. Lett. 2006, 96, 146107. [CrossRef]

167. Zeinalipour-Yazdi, C.D.; Pullman, D.P. Correlation of polarizabilities with Van der Waals interactions in $\pi$-systems. J. Phys. Chem. B 2006, 110, 24260-24265. [CrossRef]

168. Hsun Su, Y.; Kai Wu, Y.; Tu, S.L.; Chang, S.J. Electrostatic studies of $\pi-\pi$ Interaction for benzene stacking on a graphene layer. Appl. Phys. Lett. 2011, 99, 163102. [CrossRef]

169. De Moraes, E.E.; Tonel, M.Z.; Fagan, S.B.; Barbosa, M.C. Density functional theory study of $\pi$-aromatic interaction of benzene, phenol, catechol, dopamine isolated dimers and adsorbed on graphene surface. J. Mol. Model. 2019, 25, 302. [CrossRef]

170. Ershova, O.V.; Lillestolen, T.C.; Bichoutskaia, E. Study of polycyclic aromatic hydrocarbons adsorbed on graphene using density functional theory with empirical dispersion correction. Phys. Chem. Chem. Phys. 2010, 12, 6309-6329. [CrossRef] 
171. Falconer, J.L.; Madix, R.J. Desorption rate isotherms in flash desorption analysis. J. Catal. 1977, 48, $262-268$. [CrossRef]

172. Chai, J.-D.; Head-Gordon, M. Systematic optimization of long-range corrected hybrid density functionals. J. Chem. Phys. 2008, 128, 84106. [CrossRef]

173. Chai, J.-D.; Head-Gordon, M. Long-range corrected hybrid density functionals with damped atom-atom dispersion corrections. Phys. Chem. Chem. Phys. 2008, 10, 6615-6620. [CrossRef] [PubMed]

174. Boateng, L.K.; Heo, J.; Flora, J.R.V.; Park, Y.G.; Yoon, Y. Molecular level simulation of the adsorption of bisphenol A and 17a-ethinyl estradiol onto carbon nanomaterials. Sep. Purif. Technol. 2013, 116, 471-478. [CrossRef]

175. Ding, N.; Chen, X.; Wu, C.M.L. Interactions between polybrominated diphenyl ethers and graphene surface: A DFT and MD investigation. Environ. Sci. Nano 2014, 1, 55-63. [CrossRef]

176. Conti, S.; Cecchini, M. Accurate and efficient calculation of the desorption energy of small molecules from graphene. J. Phys. Chem. C 2015, 119, 1867-1879. [CrossRef]

177. Comer, J.; Chen, R.; Poblete, H.; Vergara-jaque, A.; Riviere, J.E. Predicting Adsorption Affinities of Small Molecules on Carbon Nanotubes Using Molecular Dynamics Simulation. ACS Nano 2015, 9, 11761-11774. [CrossRef] [PubMed]

178. Yu, S.; Wang, X.; Ai, Y.; Tan, X.; Hayat, T.; Hu, W.; Wang, X. Experimental and theoretical studies on competitive adsorption of aromatic compounds on reduced graphene oxides. J. Mater. Chem. A 2016, 4, 5654-5662. [CrossRef]

179. Tang, H.; Zhao, Y.; Yang, X.; Liu, D.; Shan, S.; Cui, F.; Xing, B. Understanding the pH-dependent adsorption of ionizable compounds on graphene oxide using molecular dynamics simulations. Environ. Sci. Nano 2017, 4, 1935-1943. [CrossRef]

180. Calbo, J.; López-Moreno, A.; de Juan, A.; Comer, J.; Ortí, E.; Pérez, E.M. Understanding Noncovalent Interactions of Small Molecules with Carbon Nanotubes. Chem. Eur. J. 2017, 23, 12909-12916. [CrossRef]

181. Ulbricht, H.; Zacharia, R.; Cindir, N.; Hertel, T. Thermal desorption of gases and solvents from graphite and carbon nanotube surfaces. Carbon 2006, 44, 2931-2942. [CrossRef]

182. Tait, S.L.; Dohnálek, Z.; Campbell, C.T.; Kay, B.D. n-alkanes on Pt(111) and on C (0001) Pt (111): Chain length dependence of kinetic desorption parameters. J. Chem. Phys. 2006, 125, 234308. [CrossRef]

183. Lazar, P.; Karlický, F.; Jurecka, P.; Kocman, M.; Otyepková, E.; Šafářová, K.; Otyepka, M. Adsorption of small organic molecules on graphene. J. Am. Chem. Soc. 2013, 135, 6372-6377. [CrossRef] [PubMed]

184. Scuseria, G.E. The open-shell restricted Hartree-Fock singles and doubles coupled-cluster method including triple excitations CCSD (T): application to $\mathrm{C}^{+}{ }_{3}$. Chem. Phys. Lett. 1991, 176, 27-35. [CrossRef]

185. Riley, K.E.; Pitoňák, M.; Jurečka, P.; Hobza, P. Stabilization and Structure Calculations for Noncovalent Interactions in Extended Molecular Systems Based on Wave Function and Density Functional Theories. Chem. Rev. 2010, 110, 5023-5063. [CrossRef] [PubMed]

186. Zhao, Y.; Truhlar, D.G. Density Functionals with Broad Applicability in Chemistry. Acc. Chem. Res. 2008, 41, 157-167. [CrossRef]

187. Zhao, Y.; Truhlar, D.G. The M06 suite of density functionals for main group thermochemistry, thermochemical kinetics, noncovalent interactions, excited states, and transition elements: Two new functionals and systematic testing of four M06-class functionals and 12 other function. Theor. Chem. Acc. 2008, 120, 215-241. [CrossRef]

188. Klimeš, J.; Bowler, D.R.; Michaelides, A. Chemical accuracy for the van der Waals density functional. J. Phys. Condens. Matter 2009, 22, 22201. [CrossRef] [PubMed]

189. Grimme, S. Semiempirical GGA-type density functional constructed with a long-range dispersion correction. J. Comput. Chem. 2006, 27, 1787-1799. [CrossRef]

190. Perdew, J.; Chevary, J.; Vosko, S.; Jackson, K.; Pederson, M.; Singh, D.; Fiolhais, C. Atoms, molecules, solids, and surfaces: Applications of the generalized gradient approximation for exchange and correlation. Phys. Rev. B 1992, 46, 6671-6687. [CrossRef]

191. Perdew, J.P.; Burke, K.; Ernzerhof, M. Generalized Gradient Approximation Made Simple. Phys. Rev. Lett. 1996, 77, 3865-3868. [CrossRef]

192. Perdew, J.P. Generalized gradient approximation for the exchange-correlation hole of a many-electron system. Phys. Rev. B 2014, 54, 16533-16539. [CrossRef] 
193. Credendino, R.; Minenkov, Y.; Liguori, D.; Piemontesi, F.; Melchior, A.; Morini, G.; Tolazzi, M.; Cavallo, L. Accurate experimental and theoretical enthalpies of association of $\mathrm{TiCl}_{4}$ with typical Lewis bases used in heterogeneous Ziegler-Natta catalysis. Phys. Chem. Chem. Phys. 2017, 19, 26996-27006. [CrossRef] [PubMed]

194. Bruch, L.W. Theory of physisorption interactions. Surf. Sci. 1983, 125, 194-217. [CrossRef]

195. Whitten, J.L.; Yang, H. Theory of chemisorption on metal surfaces. Surf. Sci. Rep. 1966, 218, 55-124.

196. Srinivasan, J.; Cheatham, T.E.; Cieplak, P.; Kollman, P.A.; Case, D.A. Continuum Solvent Studies of the Stability of DNA, RNA, and Phosphoramidate-DNA Helices. J. Am. Chem. Soc. 1998, 120, 9401-9409. [CrossRef]

197. Carvalho, I.T.; Santos, L. Antibiotics in the aquatic environments: A review of the European scenario. Environ. Int. 2016, 94, 736-757. [CrossRef]

198. Rusu, A.; Hancu, G.; Uivaroşi, V. Fluoroquinolone pollution of food, water and soil, and bacterial resistance. Env. Chem Lett 2015, 13, 21-36. [CrossRef]

199. Kümmerer, K. Chemosphere Antibiotics in the aquatic environment - A review - Part I. Chemosphere 2009, 75, 417-434. [CrossRef]

200. Felis, E.; Kalka, J.; Sochacki, A.; Kowalska, K.; Bajkacz, S.; Harnisz, M.; Korzeniewska, E. Antimicrobial pharmaceuticals in the aquatic environment - occurrence and environmental implications. Eur. J. Pharmacol. 2020, 866, 172813. [CrossRef]

201. Gil-Gil, T.; Laborda, P.; Sanz-García, F.; Hernando-Amado, S.; Blanco, P.; Martínez, J.L. Antimicrobial resistance: A multifaceted problem with multipronged solutions. Microbiologyopen 2019, 8, e945. [CrossRef]

202. White, A.; Hughes, J.M. Critical Importance of a One Health Approach to Antimicrobial Resistance. Ecohealth 2019, 16, 404-409. [CrossRef]

203. Miao, H.; Teng, Z.; Wang, C.; Chong, H.; Wang, G. Recent Progress in Two-Dimensional Antimicrobial Nanomaterials. Chem. Eur. J. 2019, 25, 929-944. [CrossRef] [PubMed]

204. Shi, X.; Leong, K.Y.; Ng, H.Y. Anaerobic treatment of pharmaceutical wastewater: A critical review. Bioresour. Technol. 2017, 245, 1238-1244. [CrossRef] [PubMed]

205. Pazda, M.; Kumirska, J.; Stepnowski, P.; Mulkiewicz, E. Antibiotic resistance genes identified in wastewater treatment plant systems - A review. Sci. Total Environ. 2019, 697, 134023. [CrossRef]

206. Rodríguez-Molina, D.; Mang, P.; Schmitt, H.; Chifiriuc, M.C.; Radon, K.; Wengenroth, L. Do wastewater treatment plants increase antibiotic resistant bacteria or genes in the environment? Protocol for a systematic review. Syst. Rev. 2019, 8, 304. [CrossRef]

207. Li, H.; Zhang, D.; Han, X.; Xing, B. Adsorption of antibiotic ciprofloxacin on carbon nanotubes: $\mathrm{pH}$ dependence and thermodynamics. Chemosphere 2014, 95, 150-155. [CrossRef]

208. Peng, H.; Pan, B.; Wu, M.; Liu, Y.; Zhang, D.; Xing, B. Adsorption of ofloxacin and norfloxacin on carbon nanotubes: Hydrophobicity- and structure-controlled process. J. Hazard. Mater. 2012, 233-234, 89-96. [CrossRef]

209. Ncibi, M.C.; Sillanpää, M. Optimized removal of antibiotic drugs from aqueous solutions using single, double and multi-walled carbon nanotubes. J. Hazard. Mater. 2015, 298, 102-110. [CrossRef]

210. Peixoto, P.S.; Tóth, I.V.; Segundo, M.A.; Lima, J.L.F.C. Fluoroquinolones and sulfonamides: features of their determination in water. A review. Int. J. Environ. Anal. Chem. 2016, 96, 185-202. [CrossRef]

211. Ghadim, E.E.; Manouchehri, F.; Soleimani, G.; Hosseini, H.; Kimiagar, S.; Nafisi, S. Adsorption properties of tetracycline onto graphene oxide: Equilibrium, kinetic and thermodynamic studies. PLOS ONE 2013, 8, e79254. [CrossRef]

212. Chang, P.; Jiang, W.; Li, Z.; Jean, J.; Kuo, C. Pharmaceutical Analysis Antibiotic tetracycline in the environments - A review. Res. Rev. J. Pharm. Anal. 2015, 4, 15-40.

213. Wei, J.; Sun, W.; Pan, W.; Yu, X.; Sun, G.; Jiang, H. Comparing the effects of different oxygen-containing functional groups on sulfonamides adsorption by carbon nanotubes: Experiments and theoretical calculation. Chem. Eng. J. 2017, 312, 167-179. [CrossRef]

214. Veclani, D.; Melchior, A. Adsorption of ciprofloxacin on carbon nanotubes: Insights from molecular dynamics simulations. J. Mol. Liq. 2020, 298, 111977. [CrossRef]

215. He, L.; Liu, F.; Zhao, M.; Qi, Z.; Sun, X.; Afzal, M.Z.; Sun, X.; Li, Y.; Hao, J.; Wang, S. Electronic-property dependent interactions between tetracycline and graphene nanomaterials in aqueous solution. J. Environ. Sci. (China) 2018, 66, 286-294. [CrossRef] 
216. Gao, Y.; Wu, J.; Ren, X.; Tan, X.; Hayat, T.; Alsaedi, A.; Cheng, C.; Chen, C. Impact of graphene oxide on the antibacterial activity of antibiotics against bacteria. Environ. Sci. Nano 2017, 4, 1016-1024. [CrossRef]

217. Chaban, V.V.; Savchenko, T.I.; Kovalenko, S.M.; Prezhdo, O. V Heat-Driven Release of a Drug Molecule from Carbon Nanotubes: A Molecular Dynamics Study. J. Phys. Chem. B 2010, 114, 13481-13486. [CrossRef] [PubMed]

218. Ai, Y.; Liu, Y.; Huo, Y.; Zhao, C.; Sun, L.; Han, B.; Cao, X.; Wang, X. Insights into the adsorption mechanism and dynamic behavior of tetracycline antibiotics on reduced graphene oxide (RGO) and graphene oxide (GO) materials. Environ. Sci. Nano 2019, 6, 3336-3348. [CrossRef]

219. Redgrave, L.S.; Sutton, S.B.; Webber, M.A.; Piddock, L.J. V Fluoroquinolone resistance: mechanisms, impact on bacteria, and role in evolutionary success. Trends Microbiol. 2014, 22, 438-445. [CrossRef]

220. Janencko, N.; Pokludova, L.; Blahova, J.; Svobodova, Z.; Literak, I. Implications of fluoroquinolone contamination for the aquatic environment-A review. Environ. Toxicol. Chem. 2016, 35, 2647-2656. [CrossRef]

221. Wammer, K.H.; Korte, A.R.; Lundeen, R.A.; Sundberg, J.E.; Mcneill, K.; Arnold, W.A. Direct photochemistry of three fluoroquinolone antibacterials: Norfloxacin, ofloxacin, and enrofloxacin. Water Res. 2012, 47, 439-448. [CrossRef]

222. Collignon, P.; Powers, J.H.; Chiller, T.M.; Aidara-Kane, A.; Aarestrup, F.M. World Health Organization Ranking of Antimicrobials According to Their Importance in Human Medicine: A Critical Step for Developing Risk Management Strategies for the Use of Antimicrobials in Food Production Animals. Clin. Infect. Dis. 2009, 49, 132-141. [CrossRef]

223. Nurchi, V.M.; Crisponi, G.; Lachowicz, J.I.; Zoroddu, M.A.; Peana, M.; Medici, S.; Veclani, D.; Tolazzi, M.; Melchior, A. Fluoroquinolones: A micro-species equilibrium in the protonation of amphoteric compounds. Eur. J. Pharm. Sci. 2016, 93, 380-391. [CrossRef] [PubMed]

224. Patiño, Y.; Díaz, E.; Ordóñez, S.; Gallegos-suarez, E.; Guerrero-ruiz, A. Adsorption of emerging pollutants on functionalized multiwall carbon nanotubes. Chemosphere 2015, 136, 174-180. [CrossRef] [PubMed]

225. Zhang, X.; Shen, J.; Zhuo, N.; Tian, Z.; Xu, P.; Yang, Z.; Yang, W. Interactions between Antibiotics and Graphene-Based Materials in Water: A Comparative Experimental and Theoretical Investigation. ACS Appl. Mater. Interfaces 2016, 8, 24273-24280. [CrossRef]

226. Dong, S.; Sun, Y.; Wu, J.; Wu, B.; Creamer, A.E.; Gao, B. Graphene oxide as filter media to remove levofloxacin and lead from aqueous solution. Chemosphere 2016, 150, 759-764. [CrossRef] [PubMed]

227. Yadav, S.; Goel, N.; Kumar, V.; Tikoo, K.; Singhal, S. Removal of fluoroquinolone from aqueous solution using graphene oxide: experimental and computational elucidation. Environ. Sci. Pollut. Res. 2018, 25, 2942-2957. [CrossRef] [PubMed]

228. Zhu, X.; Tsang, D.C.W.; Chen, F.; Li, S.; Yang, X. Ciprofloxacin adsorption on graphene and granular activated carbon: Kinetics, isotherms, and effects of solution chemistry. Environ. Technol. (United Kingdom) 2015, 36, 3094-3102. [CrossRef]

229. Fei, Y.; Li, Y.; Han, S.; Ma, J. Adsorptive removal of ciprofloxacin by sodium alginate/graphene oxide composite beads from aqueous solution. J. Colloid Interface Sci. 2016, 484, 196-204. [CrossRef]

230. Wu, S.; Zhao, X.; Li, Y.; Zhao, C.; Du, Q.; Sun, J.; Wang, Y.; Peng, X.; Xia, Y.; Wang, Z.; et al. Adsorption of ciprofloxacin onto biocomposite fibers of graphene oxide/calcium alginate. Chem. Eng. J. 2013, 230, 389-395. [CrossRef]

231. Ma, J.; Yang, M.; Yu, F.; Zheng, J. Water-enhanced Removal of Ciprofloxacin from Water by Porous Graphene Hydrogel. Sci. Rep. 2015, 5, 13578. [CrossRef]

232. Yu, F.; Ma, J.; Bi, D. Enhanced adsorptive removal of selected pharmaceutical antibiotics from aqueous solution by activated graphene. Environ. Sci. Pollut. Res. 2015, 22, 4715-4724. [CrossRef]

233. Carabineiro, S.A.C.; Thavorn-Amornsri, T.; Pereira, M.F.R.; Serp, P.; Figueiredo, J.L. Comparison between activated carbon, carbon xerogel and carbon nanotubes for the adsorption of the antibiotic ciprofloxacin. Catal. Today 2012, 186, 29-34. [CrossRef]

234. Yu, F.; Sun, S.; Han, S.; Zheng, J.; Ma, J. Adsorption removal of ciprofloxacin by multi-walled carbon nanotubes with different oxygen contents from aqueous solutions. Chem. Eng. J. 2016, 285, 588-595. [CrossRef] 
235. Meher, J.G.; Kesharwani, P.; Chaurasia, M.; Singh, A.; Chourasia, M.K. Chapter 14 - Carbon Nanotubes (CNTs): A Novel Drug Delivery Tool in Brain Tumor Treatment. In Nanotechnology-Based Targeted Drug Delivery Systems for Brain Tumors; Kesharwani, P., Gupta, U., Eds.; Academic Press: Cambridge, MA, USA, 2018; pp. 375-396. ISBN 978-0-12-812218-1.

236. Grossman, T.H. Tetracycline antibiotics and resistance. Cold Spring Harb. Perspect. Med. 2016, 6, a025387. [CrossRef] [PubMed]

237. Chukwudi, C.U.rRNA Binding Sites and the Molecular Mechanism of Action of the Tetracyclines. Antimicrob Agents Chemother. 2016, 60, 4433-4441. [CrossRef] [PubMed]

238. Dai, Y.; Liu, M.; Li, J.; Yang, S.; Sun, Y.; Sun, Q.; Wang, W.; Lu, L.; Zhang, K.; Xu, J.; et al. A review on pollution situation and treatment methods of tetracycline in groundwater. Sep. Sci. Technol. 2020, 55, 1005-1021. [CrossRef]

239. Gao, Y.; Li, Y.; Zhang, L.; Huang, H.; Hu, J.; Shah, S.M.; Su, X. Adsorption and removal of tetracycline antibiotics from aqueous solution by graphene oxide. J. Colloid Interface Sci. 2012, 368, 540-546. [CrossRef]

240. Yuan, X.; Wu, Z.; Zhong, H.; Wang, H.; Chen, X.; Leng, L.; Jiang, L.; Xiao, Z.; Zeng, G. Fast removal of tetracycline from wastewater by reduced graphene oxide prepared via microwave-assisted ethylenediamine-N,N'-disuccinic acid induction method. Environ. Sci. Pollut. Res. 2016, 23, 18657-18671. [CrossRef]

241. Zhang, Y.; Chen, B.; Zhang, L.; Huang, J.; Chen, F.; Yang, Z.; Yao, J.; Zhang, Z. Controlled assembly of Fe3O4 magnetic nanoparticles on graphene oxide. Nanoscale 2011, 3, 1446-1450. [CrossRef]

242. Yu, F.; Ma, J.; Han, S. Adsorption of tetracycline from aqueous solutions onto multi-walled carbon nanotubes with different oxygen contents. Sci. Rep. 2015, 4, 5326. [CrossRef]

243. Fukui, K.; Yonezawa, T.; Nagata, C.; Shingu, H. Molecular Orbital Theory of Orientation in Aromatic, Heteroaromatic, and Other Conjugated Molecules. J. Chem. Phys. 1954, 22, 1433-1442. [CrossRef]

244. Fukui, K. Role of Frontier Orbitals in Chemical Reactions. Science 1982, 218, 747-754. [CrossRef] [PubMed]

245. Ji, L.; Chen, W.; Zheng, S.; Xu, Z.; Zhu, D. Adsorption of Sulfonamide Antibiotics to Multiwalled Carbon Nanotubes. Langmuir 2009, 25, 11608-11613. [CrossRef] [PubMed]

246. Le-Minh, N.; Khan, S.J.; Drewes, J.E.; Stuetz, R.M. Fate of antibiotics during municipal water recycling treatment processes. Water Res. 2010, 44, 4295-4323. [CrossRef]

247. Arsawang, U.; Saengsawang, O.; Rungrotmongkol, T.; Sornmee, P.; Wittayanarakul, K.; Remsungnen, T.; Hannongbua, S. How do carbon nanotubes serve as carriers for gemcitabine transport in a drug delivery system? J. Mol. Graph. Model. 2011, 29, 591-596. [CrossRef]

248. Lim, D.J.; Sim, M.; Oh, L.; Lim, K.; Park, H. Carbon-based drug delivery carriers for cancer therapy. Arch. Pharm. Res. 2014, 37, 43-52. [CrossRef] [PubMed]

249. Lu, Z.R.; Qiao, P. Drug Delivery in Cancer Therapy, Quo Vadis? Mol. Pharm. 2018, 15, 3603-3616. [CrossRef] [PubMed]

250. Danhier, F.; Feron, O.; Préat, V. To exploit the tumor microenvironment: Passive and active tumor targeting of nanocarriers for anti-cancer drug delivery. J. Control. Release 2010, 148, 135-146. [CrossRef] [PubMed]

251. Zhang, J.; Chang, V.W.C.; Giannis, A.; Wang, J.Y. Removal of cytostatic drugs from aquatic environment: A review. Sci. Total Environ. 2013, 445-446, 281-298. [CrossRef]

252. Amable, L. Cisplatin resistance and opportunities for precision medicine. Pharmacol. Res. 2016, 106, $27-36$. [CrossRef]

253. Jung, Y.; Lippard, S.J. Direct cellular responses to platinum-induced DNA damage. Chem Rev 2007, 107, 1387-1407. [CrossRef]

254. Browning, R.J.; Reardon, P.J.T.; Parhizkar, M.; Pedley, R.B.; Edirisinghe, M.; Knowles, J.C.; Stride, E. Drug Delivery Strategies for Platinum-Based Chemotherapy. ACS Nano 2017, 11, 8560-8578. [CrossRef] [PubMed]

255. Johnstone, T.C.; Suntharalingam, K.; Lippard, S.J. The Next Generation of Platinum Drugs: Targeted Pt(II) Agents, Nanoparticle Delivery, and Pt(IV) Prodrugs. Chem. Rev. 2016, 116, 3436-3486. [CrossRef] [PubMed]

256. Ma, P.; Xiao, H.; Li, C.; Dai, Y.; Cheng, Z.; Hou, Z.; Lin, J. Inorganic nanocarriers for platinum drug delivery. Mater. Today 2015, 18, 554-564. [CrossRef]

257. Veclani, D.; Melchior, A.; Tolazzi, M.; Cerón-Carrasco, J.P. Using Theory to Reinterpret the Kinetics of Monofunctional Platinum Anticancer Drugs: Stacking Matters. J. Am. Chem. Soc. 2018, 140, 14024-14027. [CrossRef] 
258. Lucas, M.F.A.; Pavelka, M.; Alberto, M.E.; Russo, N. Neutral and Acidic Hydrolysis Reactions of the Third Generation Anticancer Drug Oxaliplatin. J. Phys. Chem. B 2009, 113, 831-838. [CrossRef]

259. Pavelka, M.; Lucas, M.F.A.; Russo, N. On the hydrolysis mechanism of the second-generation anticancer drug carboplatin. Chem. Eur. J. 2007, 13, 10108-10116. [CrossRef]

260. Melchior, A.; Martínez, J.M.; Pappalardo, R.R.; Sánchez Marcos, E. Hydration of Cisplatin Studied by an Effective Ab Initio Pair Potential Including Solute-Solvent Polarization. J. Chem. Theor. Comp. 2013, 9, 4562-4573. [CrossRef]

261. Melchior, A.; Sánchez Marcos, E.; Pappalardo, R.R.; Martínez, J.M. Comparative study of the hydrolysis of a third- and a first-generation platinum anticancer complexes. Theor. Chem. Acc. 2011, 128, 627-638. [CrossRef]

262. Melchior, A.; Tolazzi, M.; Martínez, J.M.; Pappalardo, R.R.; Sánchez Marcos, E. Hydration of two cisplatin aqua-derivatives studied by quantum mechanics and molecular dynamics simulations. J. Chem. Theory Comput. 2015, 11, 1735-1744. [CrossRef] [PubMed]

263. Dell'Anna, M.M.; Censi, V.; Carrozzini, B.; Caliandro, R.; Denora, N.; Franco, M.; Veclani, D.; Melchior, A.; Tolazzi, M.; Mastrorilli, P. Triphenylphosphane Pt(II) complexes containing biologically active natural polyphenols: Synthesis, crystal structure, molecular modeling and cytotoxic studies. J. Inorg. Biochem. 2016, 163. [CrossRef]

264. Kazemi-Beydokhti, A.; Zeinali Heris, S.; Jaafari, M.R. Investigation of different methods for cisplatin loading using single-walled carbon nanotube. Chem. Eng. Res. Des. 2016, 112, 56-63. [CrossRef]

265. Ajima, K.; Murakami, T.; Mizoguchi, Y.; Tsuchida, K.; Ichihashi, T.; Iijima, S.; Yudasaka, M. Enhancement of in vivo anticancer effects of cisplatin by incorporation inside single-wall carbon nanohorns. ACS Nano 2008, 2, 2057-2064. [CrossRef] [PubMed]

266. Ajima, K.; Yudasaka, M.; Maigné, A.; Miyawaki, J.; Iijima, S. Effect of functional groups at hole edges on cisplatin release from inside single-wall carbon nanohorns. J. Phys. Chem. B 2006, 110, 5773-5778. [CrossRef] [PubMed]

267. Hampel, S.; Kunze, D.; Haase, D.; Krämer, K.; Rauschenbach, M.; Ritschel, M.; Leonhardt, A.; Thomas, J.; Oswald, S.; Hoffmann, V.; et al. Carbon nanotubes filled with a chemotherapeutic agent: A nanocarrier mediates inhibition of tumor cell growth. Nanomedicine 2008, 3, 175-182. [CrossRef]

268. Smailii, P.; Pakroo, R.; Mohammadkhani, R.; Jafarian, V.; Kabiri Esfahani, F.; Hassani, L. Decorations of graphene oxide with cisplatin toward investigation of fluorescence quencher on regulatory sequence of BRCA1 and BRCA2. J. Iran. Chem. Soc. 2020, 17, 127-134. [CrossRef]

269. Sumathra, M.; Sadasivuni, K.K.; Suresh Kumar, S.; Rajan, M. Cisplatin-Loaded Graphene Oxide/Chitosan/Hydroxyapatite Composite as a Promising Tool for Osteosarcoma-Affected Bone Regeneration. ACS Omega 2018, 3, 14620-14633. [CrossRef]

270. Tian, L.; Pei, X.; Zeng, Y.; He, R.; Li, Z.; Wang, J.; Wan, Q.; Li, X. Functionalized nanoscale graphene oxide for high efficient drug delivery of cisplatin. J. Nanoparticle Res. 2014, 16, 2709. [CrossRef]

271. Duma, A.; Prodana, M.; Demetrescu, I. Cisplatin functionalization of multiwall carbon nanotubes. UPB Sci. Bull. Ser. B Chem. Mater. Sci. 2014, 76, 49-58.

272. Almeida, E.R.; De Souza, L.A.; De Almeida, W.B.; Dos Santos, H.F. Molecular dynamics of carbon nanohorns and their complexes with cisplatin in aqueous solution. J. Mol. Graph. Model. 2019, 89, 167-177. [CrossRef]

273. Prylutskyy, Y.I.; Cherepanov, V.V.; Evstigneev, M.P.; Kyzyma, O.A.; Petrenko, V.I.; Styopkin, V.I.; Bulavin, L.A.; Davidenko, N.A.; Wyrzykowski, D.; Woziwodzka, A.; et al. Structural self-organization of $\mathrm{C}_{60}$ and cisplatin in physiological solution. Phys. Chem. Chem. Phys. 2015, 17, 26084-26092. [CrossRef]

274. Tripisciano, C.; Kraemer, K.; Taylor, A.; Borowiak-Palen, E. Single-wall carbon nanotubes based anticancer drug delivery system. Chem. Phys. Lett. 2009, 478, 200-205. [CrossRef]

275. De Souza, L.A.; Nogueira, C.A.S.; Lopes, J.F.; Dos Santos, H.F.; De Almeida, W.B. DFT study of cisplatin@carbon nanohorns complexes. J. Inorg. Biochem. 2013, 129, 71-83. [CrossRef] [PubMed]

276. De Souza, L.A.; Nogueira, C.A.S.; Lopes, J.F.; Dos Santos, H.F.; De Almeida, W.B. Theoretical study of the formation of inclusion complex between cisplatin and single-wall carbon nanotube. J. Phys. Chem. C 2015, 119, 8394-8401. [CrossRef]

277. De Souza, L.A.; Nogueira, C.A.S.; Ortega, P.F.R.; Lopes, J.F.; Calado, H.D.R.; Lavall, R.L.; Silva, G.G.; Dos Santos, H.F.; De Almeida, W.B. Inclusion complex between cisplatin and single-walled carbon nanotube: An integrated experimental and theoretical approach. Inorganica Chim. Acta 2016, 447, 38-44. [CrossRef] 
278. De Souza, L.A.; Dos Santos, H.F.; Costa, L.T.; De Almeida, W.B. Inclusion complexes between cisplatin and oxidized carbon nanostructures: A theoretical approach. J. Inorg. Biochem. 2018, 178, 134-143. [CrossRef] [PubMed]

279. Del Cuevas-Flores, M.R.; Garcia-Revilla, M.A.; Bartolomei, M. Noncovalent interactions between cisplatin and graphene prototypes. J. Comput. Chem. 2018, 39, 71-80. [CrossRef] [PubMed]

280. Panczyk, T.; Jagusiak, A.; Pastorin, G.; Ang, W.H.; Narkiewicz-Michalek, J. Molecular dynamics study of cisplatin release from carbon nanotubes capped by magnetic nanoparticles. J. Phys. Chem. C 2013, 117, 17327-17336. [CrossRef]

281. Panczyk, T.; Da Ros, T.; Pastorin, G.; Jagusiak, A.; Narkiewicz-Michalek, J. Role of intermolecular interactions in assemblies of nanocontainers composed of carbon nanotubes and magnetic nanoparticles: A molecular dynamics study. J. Phys. Chem. C 2014, 118, 1353-1363. [CrossRef]

282. Panczyk, T.; Wolski, P.; Konczak, L.; Narkiewicz-Michalek, J. Sidewall functionalization of carbon nanotubes as a method of controlling structural transformations of the magnetically triggered nanocontainer: A molecular dynamics study. J. Phys. Chem. C 2015, 119, 8373-8381. [CrossRef]

283. Mejri, A.; Vardanega, D.; Tangour, B.; Gharbi, T.; Picaud, F. Encapsulation into carbon nanotubes and release of anticancer cisplatin drug molecule. J. Phys. Chem. B 2015, 119, 604-611. [CrossRef]

284. Mehrjouei, E.; Akbarzadeh, H.; Shamkhali, A.N.; Abbaspour, M.; Salemi, S.; Abdi, P. Delivery of Cisplatin Anti-Cancer Drug from Carbon, Boron Nitride, and Silicon Carbide Nanotubes Forced by Ag-Nanowire: A Comprehensive Molecular Dynamics Study. Mol. Pharm. 2017, 14, 2273-2284. [CrossRef]

285. Hosni, Z.; Bessrour, R.; Tangour, B. ${ }^{195} \mathrm{Pt}$ chemical shift ability to control the antitumor drug cisplatin encapsulated into carbon nanotubes: A theoretical study. J. Comput. Theor. Nanosci. 2014, 11, 318-323. [CrossRef]

286. Stephens, P.J.; Devlin, F.J.; Chabalowski, C.F.; Frisch, M.J. Ab Initio Calculation of Vibrational Absorption and Circular Dichroism Spectra Using Density Functional Force Fields. J. Phys. Chem. 1994, 98, 11623-11627. [CrossRef]

287. Cagel, M.; Grotz, E.; Bernabeu, E.; Moretton, M.A.; Chiappetta, D.A. Doxorubicin: nanotechnological overviews from bench to bedside. Drug Discov. Today 2017, 22, 270-281. [CrossRef] [PubMed]

288. Bouma, J.; Beijnen, J.H.; Bult, A.; Underberg, W.J.M. Anthracycline antitumour agents. Pharm. Weekbl. 1986, 8, 109-133. [CrossRef]

289. Yang, F.; Teves, S.S.; Kemp, C.J.; Henikoff, S. Doxorubicin, DNA torsion, and chromatin dynamics. Biochim. Biophys. Acta Rev. Cancer 2014, 1845, 84-89. [CrossRef] [PubMed]

290. Shafei, A.; El-Bakly, W.; Sobhy, A.; Wagdy, O.; Reda, A.; Aboelenin, O.; Marzouk, A.; El Habak, K.; Mostafa, R.; Ali, M.A.; et al. A review on the efficacy and toxicity of different doxorubicin nanoparticles for targeted therapy in metastatic breast cancer. Biomed. Pharmacother. 2017, 95, 1209-1218. [CrossRef] [PubMed]

291. Liu, K.; Zhang, J.J.; Cheng, F.F.; Zheng, T.T.; Wang, C.; Zhu, J.J. Green and facile synthesis of highly biocompatible graphene nanosheets and its application for cellular imaging and drug delivery. J. Mater. Chem. 2011, 21, 12034-12040. [CrossRef]

292. Sadaf, S.; Walder, L. Doxorubicin Adsorbed on Carbon Nanotubes: Helical Structure and New Release Trigger. Adv. Mater. Interfaces 2017, 4, 1700649. [CrossRef]

293. Wang, Y.; Yang, S.T.; Wang, Y.; Liu, Y.; Wang, H. Adsorption and desorption of doxorubicin on oxidized carbon nanotubes. Colloids Surf. B Biointerfaces 2012, 97, 62-69. [CrossRef]

294. Wang, F.; Liu, B.; Ip, A.C.F.; Liu, J. Orthogonal adsorption onto nano-graphene oxide using different intermolecular forces for multiplexed delivery. Adv. Mater. 2013, 25, 4087-4092. [CrossRef] [PubMed]

295. Wu, S.; Zhao, X.; Li, Y.; Du, Q.; Sun, J.; Wang, Y.; Wang, X.; Xia, Y.; Wang, Z.; Xia, L. Adsorption properties of doxorubicin hydrochloride onto graphene oxide: Equilibrium, kinetic and thermodynamic studies. Materials 2013, 6, 2026-2042. [CrossRef] [PubMed]

296. Wu, S.; Zhao, X.; Cui, Z.; Zhao, C.; Wang, Y.; Du, L.; Li, Y. Cytotoxicity of graphene oxide and graphene oxide loaded with doxorubicin on human multiple myeloma cells. Int. J. Nanomed. 2014, 9, 1413-1421.

297. Zhang, W.; Guo, Z.; Huang, D.; Liu, Z.; Guo, X.; Zhong, H. Synergistic effect of chemo-photothermal therapy using PEGylated graphene oxide. Biomaterials 2011, 32, 8555-8561. [CrossRef]

298. Izadyar, A.; Farhadian, N.; Chenarani, N. Molecular dynamics simulation of doxorubicin adsorption on a bundle of functionalized CNT. J. Biomol. Struct. Dyn. 2016, 34, 1797-1805. [CrossRef] 
299. Mahdavi, M.; Rahmani, F.; Nouranian, S. Molecular simulation of $\mathrm{pH}$-dependent diffusion, loading, and release of doxorubicin in graphene and graphene oxide drug delivery systems. J. Mater. Chem. B 2016, 4, 7441-7451. [CrossRef]

300. Mirhosseini, M.M.; Rahmati, M.; Zargarian, S.S.; Khordad, R. Molecular dynamics simulation of functionalized graphene surface for high efficient loading of doxorubicin. J. Mol. Struct. 2017, 1141, 441-450. [CrossRef]

301. Contreras, M.L.; Torres, C.; Villarroel, I.; Rozas, R. Molecular dynamics assessment of doxorubicin-carbon nanotubes molecular interactions for the design of drug delivery systems. Struct. Chem. 2019, 30, 369-384. [CrossRef]

302. Kordzadeh, A.; Amjad-Iranagh, S.; Zarif, M.; Modarress, H. Adsorption and encapsulation of the drug doxorubicin on covalent functionalized carbon nanotubes: A scrutinized study by using molecular dynamics simulation and quantum mechanics calculation. J. Mol. Graph. Model. 2019, 88, 11-22. [CrossRef]

303. Tonel, M.Z.; Martins, M.O.; Zanella, I.; Pontes, R.B.; Fagan, S.B. A first-principles study of the interaction of doxorubicin with graphene. Comput. Theor. Chem. 2017, 1115, 270-275. [CrossRef]

304. Vovusha, H.; Banerjee, D.; Yadav, M.K.; Perrozzi, F.; Ottaviano, L.; Sanyal, S.; Sanyal, B. Binding Characteristics of Anticancer Drug Doxorubicin with Two-Dimensional Graphene and Graphene Oxide: Insights from Density Functional Theory Calculations and Fluorescence Spectroscopy. J. Phys. Chem. C 2018, 122, 21031-21038. [CrossRef]

305. Rowinsky, E.K.; Cazenave, L.A.; Donehower, R.C. Taxol: A novel investigational antimicrotubule agent. J. Natl. Cancer Inst. 1990, 82, 1247-1259. [CrossRef]

306. Liu, Y.; Zhang, B.; Yan, B. Enabling anticancer therapeutics by nanoparticle carriers: The delivery of paclitaxel. Int. J. Mol. Sci. 2011, 12, 4395-4413. [CrossRef] [PubMed]

307. Liu, Z.; Robinson, J.T.; Tabakman, S.M.; Yang, K.; Dai, H. Carbon materials for drug delivery \& cancer therapy. Mater. Today 2011, 14, 316-323.

308. Berlin, J.M.; Pham, T.T.; Sano, D.; Mohamedali, K.A.; Marcano, D.C.; Myers, J.N.; Tour, J.M. Noncovalent functionalization of carbon nanovectors with an antibody enables targeted drug delivery. ACS Nano 2011, 5 , 6643-6650. [CrossRef] [PubMed]

309. Rezaian, M.; Maleki, R.; Dahri Dahroud, M.; Alamdari, A.; Alimohammadi, M. pH-Sensitive Co-Adsorption/Release of Doxorubicin and Paclitaxel by Carbon Nanotube, Fullerene, and Graphene Oxide in Combination with N-isopropylacrylamide: A Molecular Dynamics Study. Biomolecules 2018, 8, 127. [CrossRef] [PubMed]

310. Hasanzade, Z.; Raissi, H. Investigation of graphene-based nanomaterial as nanocarrier for adsorption of paclitaxel anticancer drug: A molecular dynamics simulation study. J. Mol. Model. 2017, 23, 36. [CrossRef] [PubMed]

311. Hashemzadeh, H.; Raissi, H. The functionalization of carbon nanotubes to enhance the efficacy of the anticancer drug paclitaxel: a molecular dynamics simulation study. J. Mol. Model. 2017, 23, 222. [CrossRef]

312. Labrie, F. Mechanism of action and pure antiandrogenic properties of flutamide. Cancer 1993, 72, $3816-3827$. [CrossRef]

313. Sufrin, G.; Coffey, D.S. Flutamide. Mechanism of action of a new nonsteroidal antiandrogen. Invest. Urol. 1976, 13, 429-434.

314. Kamel, M.; Raissi, H.; Morsali, A. Theoretical study of solvent and co-solvent effects on the interaction of Flutamide anticancer drug with Carbon nanotube as a drug delivery system. J. Mol. Liq. 2017, 248, 490-500. [CrossRef]

315. Kamel, M.; Raissi, H.; Morsali, A.; Shahabi, M. Assessment of the adsorption mechanism of Flutamide anticancer drug on the functionalized single-walled carbon nanotube surface as a drug delivery vehicle: An alternative theoretical approach based on DFT and MD. Appl. Surf. Sci. 2018, 434, 492-503. [CrossRef]

316. Tomasi, J.; Cammi, R.; Mennucci, B.; Cappelli, C.; Corni, S. Molecular properties in solution described with a continuum solvation model. Phys. Chem. Chem. Phys. 2002, 4, 5697-5712. [CrossRef]

317. Tomasi, J.; Mennucci, B.; Cammi, R. Quantum mechanical continuum solvation models. Chem. Rev. 2005, 105, 2999-3093. [CrossRef]

318. Endrizzi, F.; Di Bernardo, P.; Zanonato, P.L.; Tisato, F.; Porchia, M.; Isse, A.A.; Melchior, A.; Tolazzi, M. $\mathrm{Cu}(\mathrm{i})$ and $\mathrm{Ag}(\mathrm{i})$ complex formation with the hydrophilic phosphine 1,3,5-triaza-7-phosphadamantane in different ionic media. How to estimate the effect of a complexing medium. Dalton Trans. 2017, 46, 1455-1466. [CrossRef] 
319. Dau, P.V.; Zhang, Z.; Gao, Y.; Parker, B.F.; Dau, P.D.; Gibson, J.K.; Arnold, J.; Tolazzi, M.; Melchior, A.; Rao, L. Thermodynamic, Structural, and Computational Investigation on the Complexation between $\mathrm{UO}_{2}{ }^{2+}$ and Amine-Functionalized Diacetamide Ligands in Aqueous Solution. Inorg. Chem. 2018, 57, 2122-2131. [CrossRef]

320. Gao, Y.; Dau, P.V.; Parker, B.F.; Arnold, J.; Melchior, A.; Zhang, Z.; Rao, L. Complexation of $\mathrm{NpO}_{2}{ }^{+}$ with Amine-Functionalized Diacetamide Ligands in Aqueous Solution: Thermodynamic, Structural, and Computational Studies. Inorg. Chem. 2018, 57, 6965-6972. [CrossRef]

321. Leonzio, M.; Melchior, A.; Faura, G.; Tolazzi, M.; Zinna, F.; Di Bari, L.; Piccinelli, F. Strongly Circularly Polarized Emission from Water-Soluble Eu(III)- and Tb(III)-Based Complexes: A Structural and Spectroscopic Study. Inorg. Chem. 2017, 56, 4413-4422. [CrossRef]

322. Ghadamgahi, M.; Ajloo, D. Molecular dynamic insight into the ethanol effect on Tretinoin drug delivery through carbon nanotubes. J. Nanostruct. Chem. 2014, 4, 91. [CrossRef]

323. Saban, N.; Bujak, M. Hydroxyurea and hydroxamic acid derivatives as antitumor drugs. Cancer Chemother. Pharmacol. 2009, 64, 213-221. [CrossRef]

324. Hesabi, M.; Behjatmanesh-Ardakani, R. Investigation of carboxylation of carbon nanotube in the adsorption of anti-cancer drug: A theoretical approach. Appl. Surf. Sci. 2018, 427, 112-125. [CrossRef]

325. Sheikhi, M.; Shahab, S.; Alnajjar, R.; Ahmadianarog, M. Adsorption Properties of the New Anti-Cancer Drug Alectinib on CNT(6,6-6) Nanotube: Geometry Optimization, Molecular Structure, Spectroscopic (NMR, UV/Vis, Excited State), FMO, MEP and HOMO-LUMO Investigations. J. Clust. Sci. 2019, 30, 83-96. [CrossRef]

326. Dehneshin, N.; Raissi, H.; Hasanzade, Z.; Farzad, F. Using molecular dynamics simulation to explore the binding of the three potent anticancer drugs sorafenib, streptozotocin, and sunitinib to functionalized carbon nanotubes. J. Mol. Model. 2019, 25, 159. [CrossRef] [PubMed]

327. Iyer, R.; Fetterly, G.; Lugade, A.; Thanavala, Y. Sorafenib: A clinical and pharmacologic review. Expert Opin. Pharmacother. 2010, 11, 1943-1955. [CrossRef]

328. Wilhelm, S.; Carter, C.; Lynch, M.; Lowinger, T.; Dumas, J.; Smith, R.A.; Schwartz, B.; Simantov, R.; Kelley, S. Discovery and development of sorafenib: A multikinase inhibitor for treating cancer. Nat. Rev. Drug Discov. 2006, 5, 835-844. [CrossRef]

329. Bagcchi, S. Sunitinib still first-line therapy for metastatic renal cancer. Lancet. Oncol. 2014, 15, e420. [CrossRef]

330. Nocera, M.; Baudin, E.; Pellegriti, G.; Cailleux, A.F.; Mechelany-Corone, C.; Schlumberger, M. Treatment of advanced medullary thyroid cancer with an alternating combination of doxorubicin-streptozocin and 5 FU-dacarbazine. Br. J. Cancer 2000, 83, 715-718. [CrossRef]

331. Szkudelski, T. The mechanism of alloxan and streptozotocin action in B cells of the rat pancreas. Physiol. Res. 2001, 50, 537-546.

(C) 2020 by the authors. Licensee MDPI, Basel, Switzerland. This article is an open access article distributed under the terms and conditions of the Creative Commons Attribution (CC BY) license (http://creativecommons.org/licenses/by/4.0/). 